\title{
Role of Calcium in Astrocyte Volume Regulation and in the Release of lons and Amino Acids
}

\author{
Edward R. O'Connor and Harold K. Kimelberg \\ Department of Pharmacology and Toxicology and Division of Neurosurgery, Albany Medical College, Albany, New York \\ 12208
}

Primary astrocyte cultures exposed to hypotonic media undergo a rapid initial swelling followed by a regulatory volume decrease (RVD), which is associated with the release of ions and amino acids. The $\mathrm{Ca}^{2+}$ dependence of RVD was investigated. Using a method that measures extracellular electrical resistance to measure cell volume changes in substratum-attached cells, we found that when astrocytes were exposed to hypotonic media without calcium, RVD was abolished. The addition of $\mathrm{CaCl}_{2}$ to astrocytes swollen in hypotonic media without calcium caused an almost immediate initiation of volume regulation, with an $\mathrm{EC}_{\mathbf{s 0}}$ of approximately $0.1 \mathrm{~mm} \mathrm{CaCl}$. Swelling of astrocytes in hypotonic medium caused an increased influx of ${ }^{45} \mathrm{Ca}^{2+}$, which was partially blocked $(60 \%)$ by $1 \mu \mathrm{M}$ nimodipine, suggesting that voltagegated L-type calcium channels were being opened. Previous work had shown that hypotonic media-induced swelling of astrocytes caused membrane potential depolarizations sufficient to open such channels (Kimelberg and O'Connor, 1988). By measuring intracellular free calcium with fura-2, we found that astrocytes swollen in hypotonic medium showed a rapid increase in $\left[\mathrm{Ca}^{2+}\right]_{n}$ reaching a peak of approximately $600 \mathrm{~nm}$, followed by a decrease to a sustained plateau (approximately $250 \mathrm{~nm}$ ) mirroring the time course of volume regulation. The removal of extracellular calcium totally abolished, and the addition of $1 \mu \mathrm{M}$ nimodipine partially abolished the elevated plateau, while neither affected the initial $\left[\mathrm{Ca}^{2+}\right.$, peak. These data suggest that the initial peak of the hypotonic-induced rise in $\left[\mathrm{Ca}^{2+} \mathrm{I}\right.$ is caused by release from intracellular stores and that the sustained elevated plateau is due to extracellular calcium influx.

The removal of extracellular calcium also abolished swelling-induced $\mathrm{K}+\left({ }^{8} \mathrm{Rb}\right)$ and ${ }^{36} \mathrm{Cl}-$ efflux, but did not affect the swelling-induced release of ${ }^{3} \mathrm{H}-\mathrm{D}$-aspartate, or ${ }^{3} \mathrm{H}$-taurine (data not shown). These data indicate that hypotonic-induced aspartate and taurine release is not necessary for RVD in astrocytes swollen by exposure to hypotonic media, since RVD is completely inhibited by the omission of external $\mathrm{Ca}^{2+}$. The addition of $1 \mathrm{~mm}$ quinine $\mathrm{HCl}$, which is known to block $\mathrm{Ca}^{2+}$ activated $\mathrm{K}+$ channels, also abolished both volume regula-

Received Aug. 27, 1992; revised Dec. 7, 1992; accepted Dec. 26, 1992.

This work was supported by Grant NS 23750 to H.K.K, and Small Instrumentation Grant HL44035 ROE awarded to Albany Medical College for purchase of the Deltascan. We thank J. Albrecht and M. Aschner for critical reading of the manuscript.

Correspondence should be addressed to H. K. Kimelberg, Ph.D., Division of Neurosurgery A-60, Albany Medical College, Albany, NY 12208.

Copyright (C) 1993 Society for Neuroscience $0270-6474 / 93 / 132638-13 \$ 05.00 / 0$ tion and ${ }^{80} \mathbf{R b}+$ efflux in hypotonic media-swollen astrocytes in the presence of medium calcium, but did not affect ${ }^{3} \mathrm{H}$ D-aspartate efflux. We suggest that the swelling of astrocytes in hypotonic media which leads to a rapid membrane depolarization first opens voltage-gated calcium channels. Extracellular $\mathrm{Ca}^{2+}$ then enters the cell, leading to a sustained increase in intracellular free calcium $\left(\left[\mathrm{Ca}^{2+}\right]_{1}\right)$, triggering activation of $\mathrm{Ca}^{2+}$-dependent ion channels and the release of $\mathrm{K}^{+}$and $\mathrm{Cl}^{-}$followed by osmotically obligated water, thus leading to RVD. Although intimately associated with this process, swelling-induced release of amino acids, because of its independence of extracellular $\mathrm{Ca}^{2+}$, does not seem to be involved in RVD.

[Key words: cell swelling, volume regulation, regulatory volume decrease, volume measurements, astrocytes, monolayer cultures, extracellular impedance, fura-2, intracellular calcium, potassium, chloride, aspartatel

Most vertebrate cells, when swollen by exposure to hypotonic media, are capable of returning to ncar normal volumes by a process known as regulatory volume decrease (RVD) (for recent reviews, see Chamberlin and Strange, 1989; Hoffmann and Simonsen, 1989; Grinstein and Foskett, 1990; Hoffmann and Kolb, 1991). RVD is achieved by the release of intracellular osmolytes (principally $\mathrm{K}^{+}$and $\mathrm{Cl}^{-}$, and/or amino acids), causing osmotically obligated water to follow and allowing the cell to return toward its original volume. As in other vertebrate cells, mammalian glial cells respond to exposure to hypotonic media by rapidly swelling and then undergoing RVD, as first described by Kimelberg and Frangakis (1985) and Olson et al. (1986) for primary astrocyte monolayer cultures and for $\mathrm{C}_{6}$ glioma cells by Kempski et al. (1983). For recent reviews of cell volume regulation in astrocytes and other cells in the mammalian nervous system, see Kimelberg (1991) and Ballanyi and Grafe (1988).

Understanding the intracellular signals that initiate and/or control RVD is of considerable interest, and both extracellular and intracellular $\mathrm{Ca}^{2}$ has been shown to influence cell volume regulation in a number of cell types (Foskett and Spring, 1985; Cala et al., 1986; Eveloff and Warnock, 1987; Foskett and Melvin, 1989; McCarty and O'Neil, 1990; Pierce and Politis, 1990). As stated above, most vertebrate cell types accomplish volume regulation from hyposmotic stress by an efflux of $\mathrm{K}^{+}$and $\mathrm{Cl}$. In some cases removal of extracellular $\mathrm{Ca}^{2}+$ blocks volume recovery by preventing $\mathrm{KCl}$ efflux (Davis and Finn, 1987). In other instances, changes in $\left[\mathrm{Ca}^{2+}\right]_{i}$ alter volume recovery following hyposmotic stress by altcring the pattern of osmolyte efflux (Grinstein et al., 1982; Cala et al., 1986). In some cell 
types loss of $\mathrm{KCl}$ is via separate $\mathrm{K}^{+}$and $\mathrm{Cl}$ conductances (Grinstein et al., 1982; Sarkadi et al., 1984; Hoffmann et al., 1986; Eveloff and Warnock, 1987; Hazama and Okada, 1988; Rothstein and Mack, 1990), while in others the $\mathrm{K}^{+}$movement is totally $\mathrm{Cl}^{-}$dependent, suggesting the involvement of a coupled $\mathrm{KCl}$ system (Hoffmann et al., 1984; Pierce and Politis, 1990). Further evidence that $\mathrm{Ca}^{2+}$ affects $\mathrm{K}^{*}$ or $\mathrm{Cl}^{-}$channels is that quinine, a drug that inhibits $\mathrm{Ca}^{2+}$-dependent $\mathrm{K}^{+}$transport and swelling-activated $\mathrm{K}^{+}$and $\mathrm{Cl}^{-}$channels, blocks or reduces cell volume recovery (Grinstein et al., 1982; Foskett and Spring, 1985; Hoffmann et al., 1986; Hazama and Okada, 1988; Pierce and Politis, 1990; Banderali and Roy, 1992).

Examination of swelling-induced release of $\mathrm{K}^{+}, \mathrm{Cl}$, and amino acids such as glutamate, aspartate, and taurine in astrocytes is potentially relevant to many pathological states such as head trauma or stroke in the CNS where astrocytic swelling is an early and dominant event (Kimelberg, 1992). Clearance of $\mathrm{K}^{+}$has long been viewed as a major astrocyte function (Sykova, 1983; Walz, 1989), and increased extracellular levels of excitatory amino acids is thought to be one of the underlying problems in ischemic cerebral damage (Choi, 1988). Also, extracellular $\mathrm{Ca}^{2}$ + levels are known to fall during neuronal excitation and in a number of pathological states (Kimelberg and Ransom, 1986; Sykova, 1991), and some of this decrease in $\mathrm{Ca}^{2+}$ may be due to uptake into swollen astrocytes.

While efflux of amino acids has been shown to be associated with astrocytic swelling in vitro (Pasantes-Morales and Schousboe, 1988, 1989; Kimelberg et al., 1990b; Martin et al., 1990; Pasantes-Morales et al., 1990), its contribution to RVD has not been defined. Thus, for this reason and for its relevance to neurotransmitter release in general, we considered it important to determine the role of $\mathrm{Ca}^{2+}$ in both amino acid and $\mathrm{KCl}$ release and RVD. The present study thus had the following objectives: (1) to explore the involvement of calcium in hypotonic-induced astrocytic swelling and RVD, (2) to characterize the routes of swelling-induced calcium entry, (3) to determine if changes in $\left[\mathrm{Ca}^{2+}\right]$, acts as an intracellular signal for volume regulation, and (4) to determine what contributions the release of $\mathrm{K}^{+}, \mathrm{Cl}^{-}$, and the amino acids aspartate and taurinc make to volume regulation in primary astrocyte cultures.

Parts of these data have been presented in abstract form (O’Connor and Kimelberg, 1991).

\section{Materials and Methods}

Materials. All cell culture materials were from GIBCO (Grand Island, NY). Other chemicals were from Sigma (St. Louis, MO). All radiolabeled ions and amino acids were obtained from Amersham Corporation (Arlington Heights, IL). Fura 2/AM was obtained from Molecular Probes (Eugene, OR).

Astrocyte cultures. Primary astrocyte cultures were prepared from the cerebral cortex of neonatal rats after dissociation with a neutral protease as previously described by Frangakis and Kimelberg (1984), and grown in multi-well trays, on glass coverslips or on cell support film for the perfusion studies (Bellco Biotechnology, Inc., Vineland, NJ). Cultures were used upon reaching confluency, usually after 3-4 weeks, and showed $\geq 95 \%$ staining for the astrocytic-specific marker glial fibrillary acidic protein.

The control bathing medium for all experiments, unless otherwise noted, consisted of $122 \mathrm{mM} \mathrm{NaCl}, 3.3 \mathrm{mM} \mathrm{KCl}, 1.2 \mathrm{mM} \mathrm{KH}_{2} \mathrm{PO}_{4}, 1.3$ $\mathrm{mM} \mathrm{CaCl}_{2}, 0.4 \mathrm{~mm} \mathrm{MgSO}, 10 \mathrm{~mm} \mathrm{D}-(t)$-glucose, and either $25 \mathrm{~mm}$ $\mathrm{NaHCO}_{3}$ or HEPES. This isotonic media was maintained at $\mathrm{pH} 7.4$ by bubbling with $5 \% \mathrm{CO}_{2}$ for the bicarbonate-buffered solution, or addition of $\mathrm{NaOH}$ to the HEPES-buffered solution. Hyposmotic media were made by removing specific amounts of $\mathrm{NaCl}$ from the initial recipe.

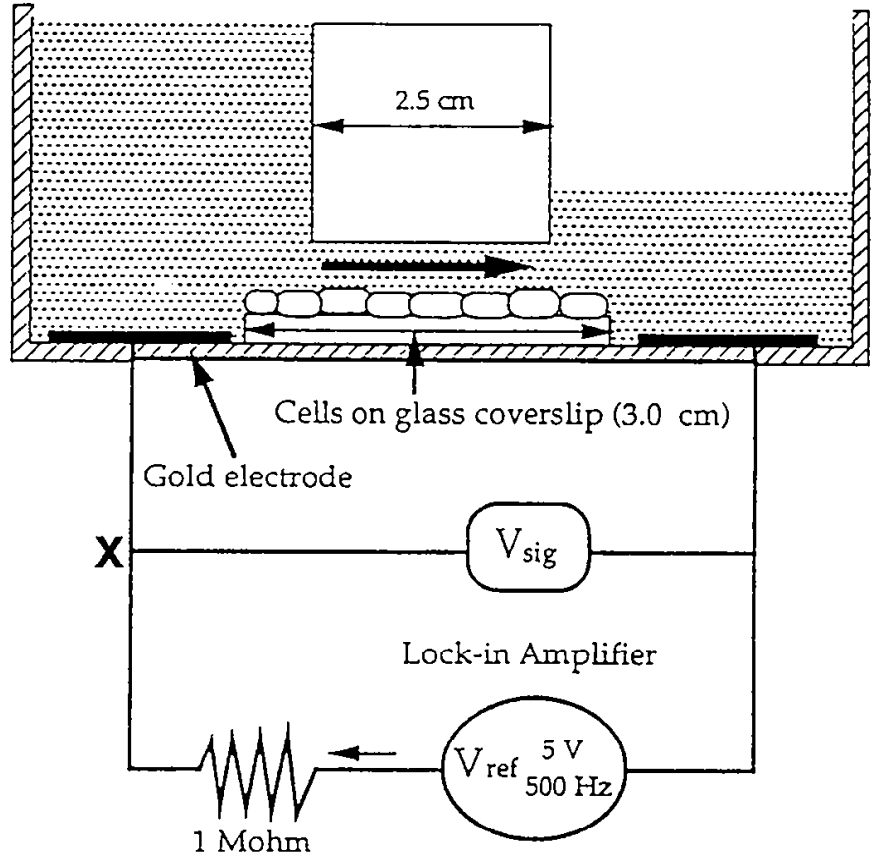

Figure 1. Schematic of the chamber used for electrical resistance measurements of volume changes in substratum-attached astrocytes. The lock-in amplifier both supplies a reference voltage and measures changes in the signal voltage at point $X$, thus acting as a voltage divider. The system is set up with a large external resistance ( $1 \mathrm{M} \Omega$ ) much greater than the chamber resistance so that the current $i$ is constant. The height of the fluid-filled channel above the cells is approximately $100 \mu \mathrm{m}$. Dimensions are not to scale (see Measurement of cell volume for details).

The osmolarity of all solutions was checked using a vapor pressure osmometer (Westcor Inc.).

Measurement of cell volume. A complete description detailing this method can be found in O'Connor et al. (1993), and this and other methods for measuring cell volume are reviewed in Kimelberg et al. (1992). Briefly, in this method cells are placed in a confined channel containing a salt solution and the electrical resistance of the channel measured using an applied alternating current (AC) (see Fig. 1). If the volume of the cells increases, then the volume of the solution within the channel available for current conduction decreases by the same amount, and consequently the measured resistance increases. This method allows for continuous measurements of volume changes in substratum-attached cultures. Gold-plated, low-impedance, inert electrodes are secured to the bottoms of two chambers, separated by the cell channel, with a dab of silicone grease. Leads from the gold electrodes, made of insulated copper wire, are soldered to the gold with pure indium and the connections covered in wax. The gold electrodes are connectcd through a large resistor (1 M $)$ to a lock-in amplifier (5301, EG\&G Princeton Applied Research, Princeton, NJ) and a $500 \mathrm{~Hz}, 5 \mathrm{~V}$ signal is supplied to the system. The lock-in amplifier is used because it is able to resolve small voltage changes with high noise rejection. Apart from the solution in the channel, the two chambers are insulated from each other (Fig. 1).

The isosmotic, control bathing medium for the electrical resistance measurements consisted of $72 \mathrm{mM} \mathrm{NaCl}, 100 \mathrm{~mm}$ sucrose, $3.3 \mathrm{~mm} \mathrm{KCl}$, $1.2 \mathrm{mM} \mathrm{KH}_{2} \mathrm{PO}_{4}, 1.3 \mathrm{mM} \mathrm{CaCl}_{2}, 0.4 \mathrm{mM} \mathrm{MgSO}_{4}, 10 \mathrm{~mm} \mathrm{D-(+)-glucose,}$ and $25 \mathrm{~mm}$ HEPES, adjusted to $\mathrm{pH} 7.4$ by addition of $1 \mathrm{~N} \mathrm{NaOH}$. Hyposmotic media were made by removing sucrose. The replacement of part of the $\mathrm{NaCl}$ with sucrose had the important feature of maintaining the same electrolyte concentration in the respective iso- and hyposmotic buffers, resulting in almost identical resistivities for these two solutions. However, a small correction had to be made for a small decrease in solution conductance due to sucrose, which was corrected for by adding a small amount of water (see below). It is clearly critical to balance the test solutions to the same resistivity so that the resistance differences measured when the solutions are changed is only due to changes in cell volume. The resistivities of solutions were checked by placing two gold electrodes (described below) $1 \mathrm{~cm}$ apart and measuring the resistivity 
directly with a $5 \mathrm{~V}, 500 \mathrm{~Hz}$ AC signal. The resistivities of paired isosmotic and hyposmotic solutions were then balanced to within $0.5 \%$ by adding small amounts of distilled water or $\mathrm{NaCl}$.

To begin an experiment, a \#1 coverslip $(3.0 \mathrm{~cm} \times 1.4 \mathrm{~cm})$ on which a confluent monolayer of astrocytes was growing was placed in the channel and continuously perfused with isotonic solution at $25^{\circ} \mathrm{C}$, the flow bcing driven by the height difference of solutions in the neighboring chambers (Fig. 1). An initial resistance was measured and normalized to 1.0 , and subsequent changes in resistance were represented as a percentage change from the initial value. The chamber was designed to have a height of approximately $100 \mu \mathrm{m}$ above the cells. This becomes convenient because, since we measure the percentage change in resistance, a $1 \%$ change in the measurement translates approximately directly to a $1 \mu \mathrm{m}$ change in the average cell height of the monolayer. This linear relationship of normalized resistance to cell height only applies over a two- to threefold change in cell volume. To exchange solutions the isotonic buffer was $99 \%$ removed and replaced with an equal amount of the challenge buffer, with $90 \%$ of this amount being placed on one side of the channel and $10 \%$ on the other. It took approximately 3-5 $\sec$ for the new solution to bathe the cells completely. At the end of each expcrimental series, the coverslip was viewed under a microscope to confirm the astrocyte monolayer was intact, and the cell viability was assessed by trypan blue exclusion $(0.08 \%$; GIBCO).

${ }^{45} \mathrm{Ca}^{2+}$ uptake studies. For these experiments, cells were grown in $12-$ well trays (Costar), the growth media aspirated off and the cells washed three times with the balanced salt solution (see above). The cells were then incubated in this medium for $30 \mathrm{~min}$ at $37^{\circ} \mathrm{C}$. These media were then aspirated and $0.5 \mathrm{ml}$ of the same isotonic or a hypotonic solution, warmed to $37^{\circ} \mathrm{C}$ and containing $0.5 \mu \mathrm{Ci}$ of ${ }^{45} \mathrm{Ca}(\mathrm{S}$.A., $2 \mathrm{Ci} / \mu \mathrm{l}$; Amersham), was added to each well. The cells were then returned to the incubator. At the desired times this medium was aspirated from each well and each well was washed four times with $1 \mathrm{ml}$ per wash of icecold $0.29 \mathrm{M}$ mannitol solution, also containing $10 \mathrm{~mm}$ Tris nitrate and $0.5 \mathrm{~mm} \mathrm{Ca}\left(\mathrm{NO}_{3}\right)_{2}$, pH 7.4 (Kimelberg et al., 1990b). The omission of $\mathrm{Na}^{+}$from the washing fluid prevents efflux of $\mathrm{Ca}^{2+}$ during the washing procedure by $\mathrm{Na}^{+} / \mathrm{Ca}^{2+}$ exchange (due to lack of $\mathrm{Na}^{+}$) and by ATPdependent extrusion of $\mathrm{Ca}^{2+}$ (due to lowering of the temperature). A fifth wash with the above mannitol wash plus 1 mM EGTA was performed to remove any surface-bound calcium (Walz and Wilson, 1986). The cell monolayer from each well was then solubilized in $1 \mathrm{ml}$ of $1 N$ $\mathrm{NaOH}$ at room temperature for $20 \mathrm{~min}$ and cell protein was determined using the Pierce bicinchoninic acid reagent as modified for use in monolayer cell cultures (Goldschmidt and Kimelberg, 1989). ${ }^{45} \mathrm{Ca}^{2+}$ samples were measured by liquid scintillation counting.

Measurement of intracellular calcium. Measurements of $\left[\mathrm{Ca}^{2+}\right]_{i}$ were made using the fluorescent calcium chelator fura-2 and a Deltascan I System for dual-wavelength microspectrofluorimetry (Photon Technology International Inc., Princeton, NJ) attached to an inverted Nikon Diaphot microscope. Astrocytes grown on $13.8 \times 30 \mathrm{~mm}^{2}$ glass coverslips were loaded with fura-2 by incubating the cells with $5 \mu \mathrm{M}$ fura$2 / \mathrm{AM}$ for $30 \mathrm{~min}$ at $37^{\circ} \mathrm{C}$ in serum-free minimal essential medium. The astrocytes were then incubated in isotonic salt buffer (see above) without fura-2/AM for $30 \mathrm{~min}$ at $37^{\circ} \mathrm{C}$ to ensure complete hydrolysis of the ester. Fluorescent measurements were made at excitation wavelengths of 340 and $380 \mathrm{~nm}$ with the emission wavelength set at $500 \mathrm{~nm}$. Cytosolic free calcium was determined as previously described by Cobbold and Rink (1987).

Efflux studies. Efflux studies were performed using a continuous perfusion method essentially the same as that described by Shain and Martin (1984), using cells grown to confluency on plastic cell support film. The cells were loaded, usually overnight, in growth media with $0.4 \mu \mathrm{Ci}$ of $\mathrm{D}-\left[2,3-{ }^{3} \mathrm{H}\right]$-aspartic acid (S.A., $26 \mathrm{Ci} / \mathrm{mmol}$ ) plus unlabeled $D$-aspartate for a final concentration of $100 \mu \mathrm{m}$ aspartate, or $0.4 \mu \mathrm{Ci}$ of $\left[1,2-{ }^{3} \mathrm{H}\right]$-taurine (S.A., $35 \mathrm{Ci} / \mathrm{mmol}$ ) plus unlabeled taurine for a final concentration of $50 \mu \mathrm{M}$ taurine, or for $2 \mathrm{hr}$ with $40-100 \mu \mathrm{Ci}$ of ${ }^{86} \mathrm{Rb}^{+}$ (for $\mathrm{K}^{+}$) or $40-100 \mu \mathrm{Ci}$ of ${ }^{36} \mathrm{Cl}^{-} .{ }^{3} \mathrm{H}$-D-aspartate was used as a nonmetabolizable analog of L-glutamate or L-aspartate. The support film was then carefully rolled into a cylinder, cells facing inward, and inserted into a $1 \mathrm{ml}$ plastic syringe and continuously perfused with $37^{\circ} \mathrm{C}$ buffer using a gravity-driven system at a rate of $1 \mathrm{ml} / \mathrm{min}$, and fractions were collected every minute. Four milliliters of Ecoscint (National Diagnostics, Manville, NJ) were added to each $1 \mathrm{ml}$ fraction, which were then counted in a Packard Tri-Carb 1900TR Liquid Scintillation Analyzer (Packard Instrument Co., Meriden, CT). Recent work in our laboratory has shown that after labeling the cells with both ${ }^{51} \mathrm{Cr}$ (chromium as
$\mathrm{Na}^{51} \mathrm{CrO}_{4}$ ) and ${ }^{3} \mathrm{H}-\mathrm{D}$-aspartate, exposure to hypotonic medium causes increased loss of ${ }^{3} \mathrm{H}$-D-aspartate but does not cause the appearance of ${ }^{51} \mathrm{Cr}$ in the effluent. This further supports the view that we are observing true efflux of ions and amino acids and that the released label is not due to loss or lysis of cells (H. K. Kimelberg, D. J. Bonville, and S. K Goderie, unpublished observations). Efflux of ions or amino acids was expressed as fractional release of the radioactivity in the cells at each time point. A computer program developed in our laboratories calculated the percentage efflux by adding back the effluxed radioactivity to each point, including the final radioactivity counted in the cell support film, thus correcting for loss of label in the cells over time.

\section{Results}

Effect of $\mathrm{Ca}^{2+}$ on $\mathrm{RVD}$. The volume measurement experiments were done using the electrical resistance method described above. As noted in Materials and Methods, Figure 1 is a representation of the chamber used to make the volume measurements in the astrocytes. A recorded increase in the resistance means that the volume through the channel above the cells available for current flow has decreased by the same amount that the volume of the cell monolayer has increased. If the cells shrink or volume regulate after swelling, this would be recorded as a decrease in resistance. The upper trace in Figure $2 A$ is an example of the response of astrocytes seen upon exposure to hyposmotic media (minus 100 mм sucrose; see caption and Materials and Methods). The astrocytes initially swell, as shown by the increase in normalized resistance, and reach a peak of swelling at approximately $3 \mathrm{~min}$. The cells then begin to volume regulate (RVD) back to their initial volume (as shown by the subsequent decrease in resistance). Since the height above the resting astrocytes is approximately $100 \mu \mathrm{m}$, a $1 \%$ change in resistance would equal a $1 \mu \mathrm{m}$ change in cell height, as described in Materials and Methods. 'The resting height of the astrocyte monolayer is normally 4-5 $\mu \mathrm{m}$, as determined by this method (after wiping off the cells and remeasuring the resistance), and is also supported by the work of Parsons et al. (1989) using high-voltage electron microscopy and Shain et al. (1992) using confocal microscopy on primary astrocyte monolayers. The $3.5 \%$ increase in resistance would thus indicate an approximate $3.5 \mu \mathrm{m}$ change in average cell monolayer height, or approximately a $70 \%$ increase in volume if cell volume is taken to approximate height (O'Connor et al., 1993). The bottom trace is the control response of astrocytes upon exposure to isotonic media.

In Figure $2 B$, astrocytes were exposed to hypotonic media that did not contain calcium throughout (as indicated) and it can be seen that the removal of extracellular calcium abolished volume regulation over the first $9 \mathrm{~min}$. The addition of $1 \mathrm{~mm}$ quinine $\mathrm{HCl}$ to hypotonic media in the presence of calcium (lower nonregulating trace) also abolished volume regulation. Figure $2 B$ also shows that the subsequent addition of $1 \mathrm{~mm}$ $\mathrm{CaCl}_{2}$ to swollen astrocytes in calcium-free hypotonic media (indicated by arrowhead, upper trace) caused an almost immediate initiation of volume regulation. We have found in parallel experiments that the small final concentration of calcium and the small volume $(2 \mu \mathrm{l})$ of concentrated calcium chloride ( $1 \mathrm{M}$ ) added to the hypotonic solution did not contribute to the decrease in measured resistance. Also, the addition of $2 \mu \mathrm{l}$ of 1 $\mathrm{M} \mathrm{MgCl}_{2}$ or $1 \mathrm{M} \mathrm{NaCl}$ did not cause the initiation of volume regulation (data not shown). The addition of $1 \mu \mathrm{M}$ nimodipine to hypotonic medium with calcium blocked RVD by approximately $75 \%$ (data not shown).

Figure $3 A$ shows the dose dependency of astrocyte volume regulation on added calcium. As in the experiment shown in 

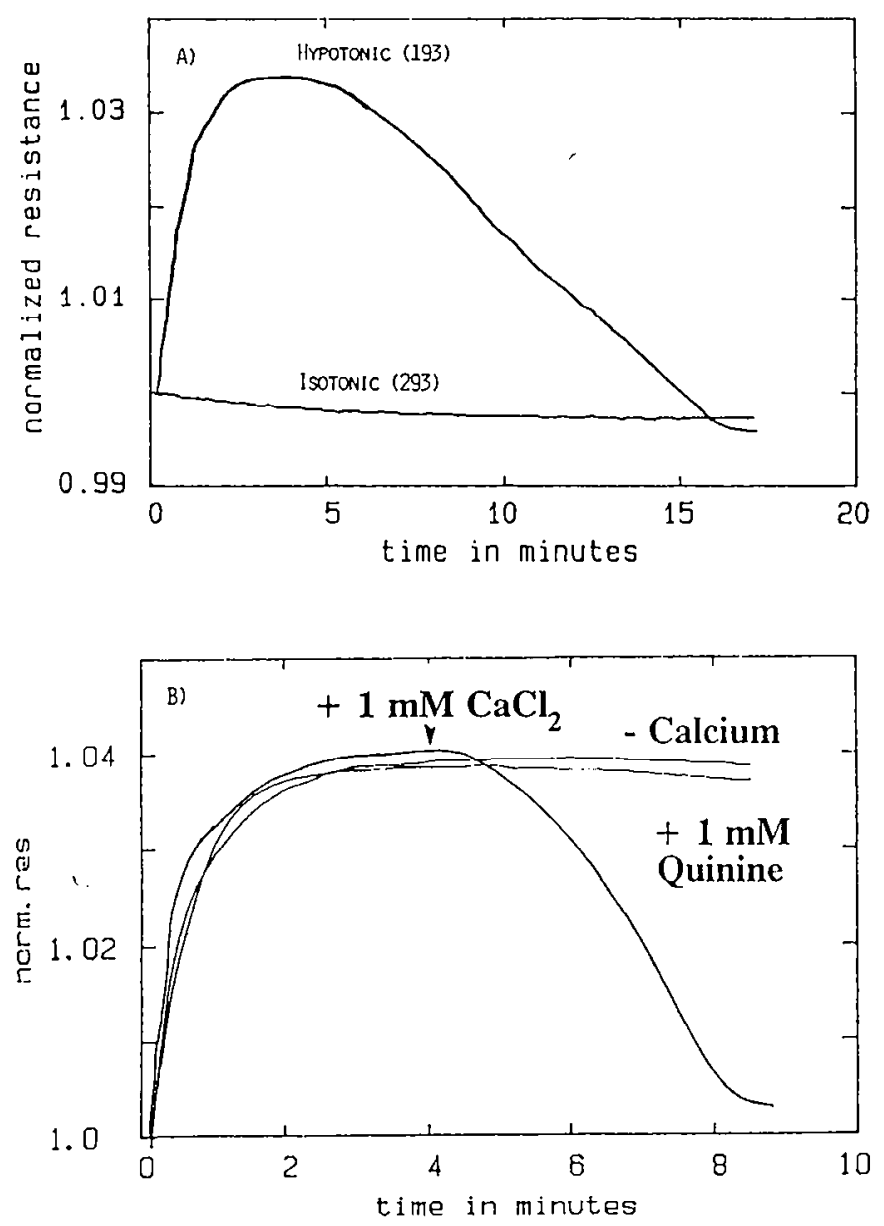

Figure 2. A, Volume changes of astrocytes, represented by the percentage change in normalized resistance, upon exposure to a hypotonic solution. Hypotonic solutions were made by removal of $100 \mathrm{~mm}$ sucrose from a $293 \mathrm{mOsm} / \mathrm{kg}$ solution in which $50 \mathrm{~mm} \mathrm{NaCl}$ had been replaced by $100 \mathrm{~mm}$ sucrose. See Materials and Methods for further details. The system was first balanced in isotonic solution and the recorded resistance normalized to 1.0 . The solution was replaced with hypotonic media (or the same media for the isotonic trace) and resistance changes continuously recorded. In the bottom trace astrocytes were exposed to isotonic buffer $(293 \mathrm{mOsm} / \mathrm{kg})$, showing that the background noise of the system was quite low and stable. When astrocytes were exposed to a hypotonic solution (193 mOsm $/ \mathrm{kg}$; upper trace) there was an increase in resistance indicating an increase in cell volume. The resistance peaked between 2 and $3 \mathrm{~min}$ with a return toward normal volume within $25 \mathrm{~min}$, thus showing RVD. As described in the text (see Materials and Methods), the changes in normalized resistance arc related to changes in average volume and also the height of the cell monolayer (O'Connor et al., 1993). For example, in the top trace, the $3.5 \%$ change in resistance corresponds approximately to a $3.5 \mu \mathrm{m}$ change in cell height or a $70 \%$ increase in volume (see Effect of $\mathrm{Ca}^{2+}$ on $\mathrm{RVD}$ ). $B, \mathrm{Ca}^{2+}$ dependency of astrocyte volume regulation as measured by the electrical resistance method. The removal of extracellular calcium (- Calcium) from hypotonic solution abolished volume regulation over the first $9 \mathrm{~min}$. The addition of $1 \mathrm{~mm}$ quinine to the hypotonic solution with calcium also abolished RVD. In the uppermost trace astrocytes were exposed to hypotonic solution minus calcium, and at time $=4 \mathrm{~min}, 1 \mathrm{mM} \mathrm{CaCl}{ }_{2}$ was added as indicated, causing an almost immediate initiation of completc volume regulation.

Figure $2 B$, astrocytes were exposed to hypotonic media without calcium, and at time $=4$ min varying concentrations of $\mathrm{Ca}^{2}$. were added as indicated. All of these responses were from the same coverslip. Since this figure comprises successive experiments on the same coverslip, the differences in the initial peak swelling are likely due to the cells not having completely re-
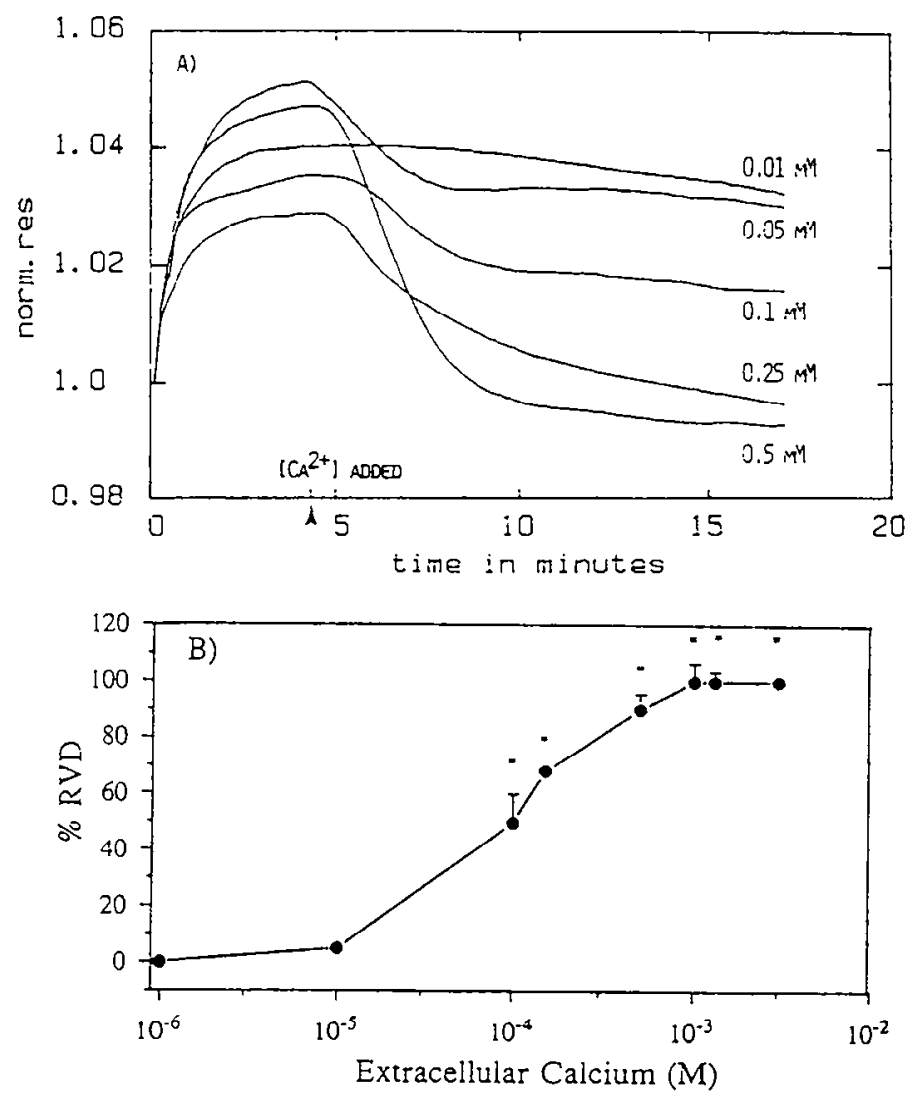

Figure 3. A, Dose dependency of RVD on extracellular calcium. Astrocytes were exposed to hypotonic solution minus calcium, and at time $=4 \mathrm{~min}$ varying concentrations of calcium were added to the external media. The addition of $0.1 \mathrm{~mm} \mathrm{CaCl}$ resulted in approximately a $50 \%$ return toward control volume while concentrations of $>0.1 \mathrm{CaCl}_{2}$ resulted in full volume recovery. These responses were from the same coverslip of cells and between cach hypotonic exposure there was a 15$20 \mathrm{~min}$ reexposure to normal isosmotic solution. The order of the experiments was as follows: $0.5,0.1,0.05,0.01,0.25 \mathrm{~mm} \mathrm{Ca}^{2+} . B$ is a plot of the data from the experiments in $A$. The ordinate expresses the $\%$ RVD from peak volume to the resting plateau after volume regulation at approximately $15-20 \mathrm{~min}$, versus added $\left[\mathrm{Ca}^{2+}\right]_{e}$. The $\left[\mathrm{Ca}^{21}\right]$, that resulted in $50 \%$ volume regulation was approximately $100 \mu \mathrm{M}$. Each point shown is the mean $+\mathrm{SD}$ from 2-10 experiments. ${ }^{*}, p<0.05$.

gained their intracellular level of osmolytes when the cells are placed back into isosmotic solution between successive exposures to hypotonic solutions (see caption for order of exposures). The addition of $0.1 \mathrm{~mm} \mathrm{CaCl} \mathrm{Cr}_{2}$ resulted in approximately a $50 \%$ return toward preswelling volumes while concentrations of $>0.1$ $\mathrm{mM} \mathrm{CaCl}{ }_{2}$ resulted in full volume recovery. For these experiments, calcium stock solutions were made so that the same 2 $\mu l$ sample size was added to the chamber to minimize the addition of water to the hypotonic solution, as this would affect its resistivity. Figure $3 B$ is a graph of the dose dependency of astrocyte volume regulation on extracellular calcium. As can be seen the $\mathrm{EC}_{50}$ for $\mathrm{Ca}^{2+}$ was approximately $100 \mu \mathrm{M}$.

${ }^{45} \mathrm{Ca}^{2+}$ uptake studies. Since RVD is dependent on extracellular calcium, we thought it likely that swelling causes increased calcium influx into the cell. Therefore, the effects of cell swelling on calcium influx were studied using ${ }^{45} \mathrm{Ca}^{2+}$. Figure $4 A$ shows the time course for uptake of ${ }^{45} \mathrm{Ca}^{2}+$ by astrocyte cultures when exposed to hypotonic media, measured over $40 \mathrm{~min}$. There is a delayed increase in ${ }^{45} \mathrm{Ca}^{2+}$ uptake after exposure to hypotonic medium. This technique measures net unidirectional influx of 

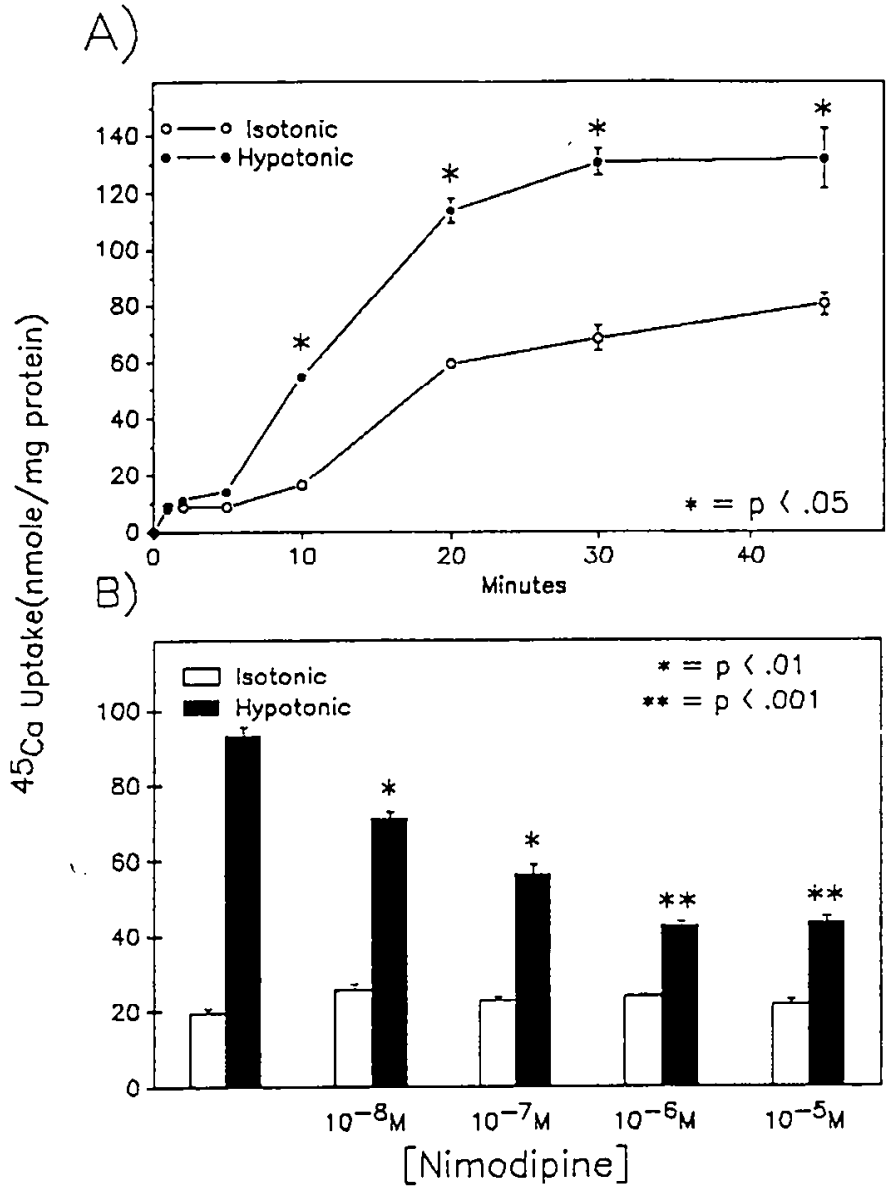

Figure 4. A, Time course of uptake of ${ }^{45} \mathrm{Ca}^{2+}$ into primary astrocyte cultures in isotonic and hypotonic media. The cells were exposed to media containing $0.5 \mu \mathrm{Ci}$ of ${ }^{45} \mathrm{Ca}^{2+}$ and then rapidly washed at the times shown. The cellular contents of ${ }^{45} \mathrm{Ca}^{2+}$ and cell protein were determined as described in Materials and Methods. As can be seen, the total ${ }^{45} \mathrm{Ca}^{2}$. uptake significantly increased when astrocytes were exposed to hypotonic media (removal of $50 \mathrm{~mm} \mathrm{NaCl}$ ), as compared to isotonic controls. Student's $t$ test analysis shows a statistical significance in ${ }^{45} \mathrm{Ca}^{2+}$ uptake in hypotonic versus isotonic media at all points including and past 10 $\min . B$ shows the effect of the voltage-sensitive calcium channel blocker nimodipine on ${ }^{45} \mathrm{Ca}^{2+}$ uptake in astrocyte cultures exposed to hypotonic media (minus $50 \mathrm{~mm} \mathrm{NaCl}$ ) measured after $20 \mathrm{~min}$. Maximal blockage of ${ }^{45} \mathrm{Ca}^{2+}$ uptake occurred with $1 \mu \mathrm{M}$ nimodipine (approximately $60 \%$ ). Student's $t$ test was used to indicate statistical significance. $n=4$ wells \pm SEM for data in both panels.

the tracer, and it is thought that the initial rise in ${ }^{45} \mathrm{Ca}^{2+}$ uptake is due to binding to the cell surface, the plateau represents entry of ${ }^{45} \mathrm{Ca}^{2+}$ into the cytosol, and the slow rise represents sequestration into the intracellular stores (Holtz et al., 1982; Meldolesi et al., 1988) (see Discussion).

Since an increase in ${ }^{45} \mathrm{Ca}^{2+}$ uptake during swelling was observed, the possible route(s) of entry for calcium into the cell was examined. Previous electrophysiology experiments had shown that swelling of the astrocytes caused a marked depolarization (Kimelberg and O'Connor, 1988), and a voltage-sensitive $\mathrm{Ca}^{2+}$ channel, resembling the L-type channel, has been described in cortical astrocytes (MacVicar, 1984; Barres et al., 1988, 1990; MacVicar and Tse, 1988; Albrecht and Lazarewicz, 1990). Therefore, the effects of voltage-sensitive $\mathrm{Ca}^{2+}$ channel blockers on the swelling-induced increase in ${ }^{45} \mathrm{Ca}^{2+}$ uptake were examined. From the data shown in Figure $4 B$, it can be seen
A)
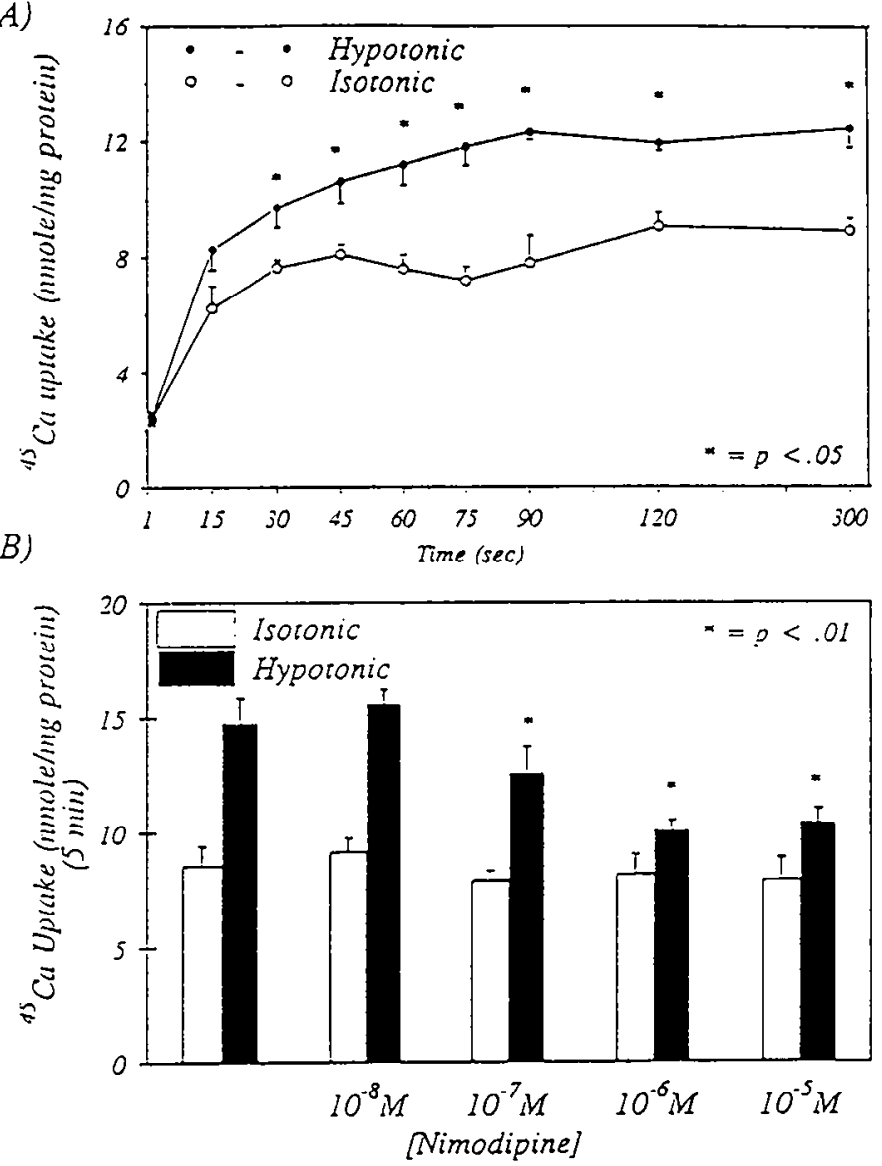

Figure 5. $A$, Swelling-induced increase in ${ }^{45} \mathrm{Ca}^{2+}$ uptake measured over $5 \mathrm{~min}$. $B$, Effect of nimodipine on ${ }^{43} \mathrm{Ca}^{2+}$ uptake ( $\mathrm{nmol} / \mathrm{mg}$ protein) at $5 \mathrm{~min}$. Maximal inhibition, approximately $66 \%$, occurred with $1 \mu \mathrm{M}$ nimodipine. Student's $t$ test was used to indicate statistical significance. $n=4$ wells \pm SEM for data in both panels.

that ${ }^{45} \mathrm{Ca}^{2+}$ uptake in hypotonic media over $20 \mathrm{~min}$ was partially blocked by increasing doses of nimodipine with a maximum block at $1 \mu \mathrm{M}$ (approximately 60\%). Nimodipine proved to be the most effective blocker while $1 \mu \mathrm{M}$ nifedipine and $10 \mu \mathrm{M}$ verapamil blocked between $40 \%$ and $50 \%$ of calcium influx (data not shown). This suggests that one route of entry for calcium during swelling is on L-type voltage-sensitive $\mathrm{Ca}^{2+}$ channels

Since, as noted above, the initial plateau seen in our experiments is thought mainly to represent the initial entry of calcium into the cytoplasm, we examined the swelling-induced ${ }^{45} \mathrm{Ca}^{2+}$ uptake over the first $5 \mathrm{~min}$ in more detail. These data are shown in Figure $5 A .{ }^{45} \mathrm{Ca}^{2+}$ uptake was significant at all points past 15 $\sec (p<0.05)$ and was also blocked approximately $66 \%$ by 1 $\mu \mathrm{M}$ nimodipine (Fig. $5 B$ ). The first $15 \mathrm{sec}$ value probably represents binding of ${ }^{45} \mathrm{Ca}^{2+}$ to the cell surface, and therefore should not be affected by nimodipine, as was seen.

Measurement of intracellular free calcium. To complement our ${ }^{45} \mathrm{Ca}^{2+}$ uptake studies, and since ${ }^{45} \mathrm{Ca}^{2+}$ is likely to enter immediately all the intracellular pools, changes in intracellular free calcium ( $\left[\mathrm{Ca}^{2+}\right]$ ) were measured during swelling and volume regulation using the fluorescent probe fura- 2 . In these experiments, fura-2-loaded astrocytes were exposed to hypotonic media (minus $50 \mathrm{mM} \mathrm{NaCl}$ ) and the change in intracellular free calcium recorded. As can be seen from Figure $6 \mathrm{~A}$ the intracellular free calcium signal given by fura- 2 rapidly increased during 

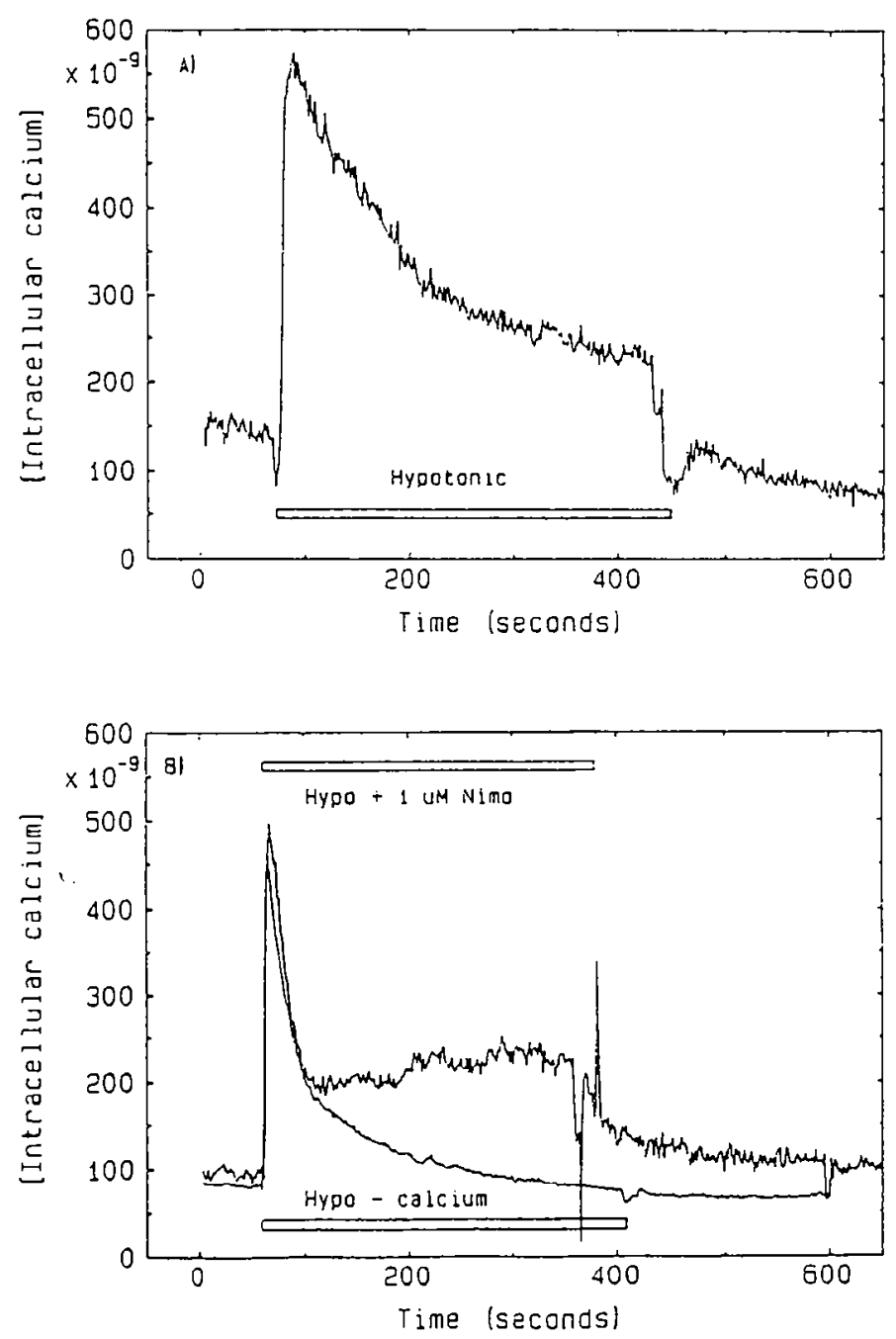

Figure 6. A, Effect of swelling of astrocytes on free $\left[\mathrm{Ca}^{2+}\right]_{\text {, as measured }}$ with fura-2. Primary astrocyte cultures were grown on coverslips and loaded with $2.5 \mu \mathrm{M}$ fura-2/AM for $30 \mathrm{~min}$. Astrocytes were exposed to hypotonic media (minus $50 \mathrm{~mm} \mathrm{NaCl}$ ) for the period shown by the open bar. $B$, Astrocytes exposed to hypotonic media minus calcium (lower trace) showed a rapid and transient increase in $\left[\mathrm{Ca}^{2+}\right]$, that quickly returned to baseline levels (within $120 \mathrm{sec}$ ) without a maintained plateau. Astrocytes exposed to hypotonic media with $\mathrm{I} \mu \mathrm{M}$ nimodipine (upper trace) also showed a rapid and transient peak of $\left[\mathrm{Ca}^{2+}\right]$, that returned to an intermediate plateau level (see Measurement of intracellular calcium). Each trace is a representative of 7-10 experiments.

exposure to hypotonic media, reaching a peak of approximately $580 \mathrm{~nm}$, and then declined with an apparent exponential time course to an elevated plateau of approximately $250 \mathrm{nM}$. When the cells were returned to isotonic media a rapid return to resting $\left[\mathrm{Ca}^{2+}\right]_{\text {i }}$ was observed. These results mirror the time course of both RVD (Fig. 2) and the membrane depolarization (Kimelberg and O'Connor, 1988) observed in astrocyte cultures during hypotonic-induced swelling. In Figure $6 B$ (lower trace), cells were exposed to hypotonic media minus calcium. They also showed a rapid initial increase in their $\left[\mathrm{Ca}^{2+}\right]$, level, but then rapidly returned to resting $\left[\mathrm{Ca}^{2+}\right]$, levels without a sustained plateau. This finding suggests that the rapid initial increase in $\left[\mathrm{Ca}^{2+}\right]$ results predominantly from swelling-activated release of intracellular $\mathrm{Ca}^{2+}$ stores and that the sustained plateau requires entry of extracellular $\mathrm{Ca}^{2+}$. Astrocytes exposed to hypotonic media plus $1 \mu_{\mathrm{M}}$ nimodipine showed three phases of calcium kinetics
A)

B)

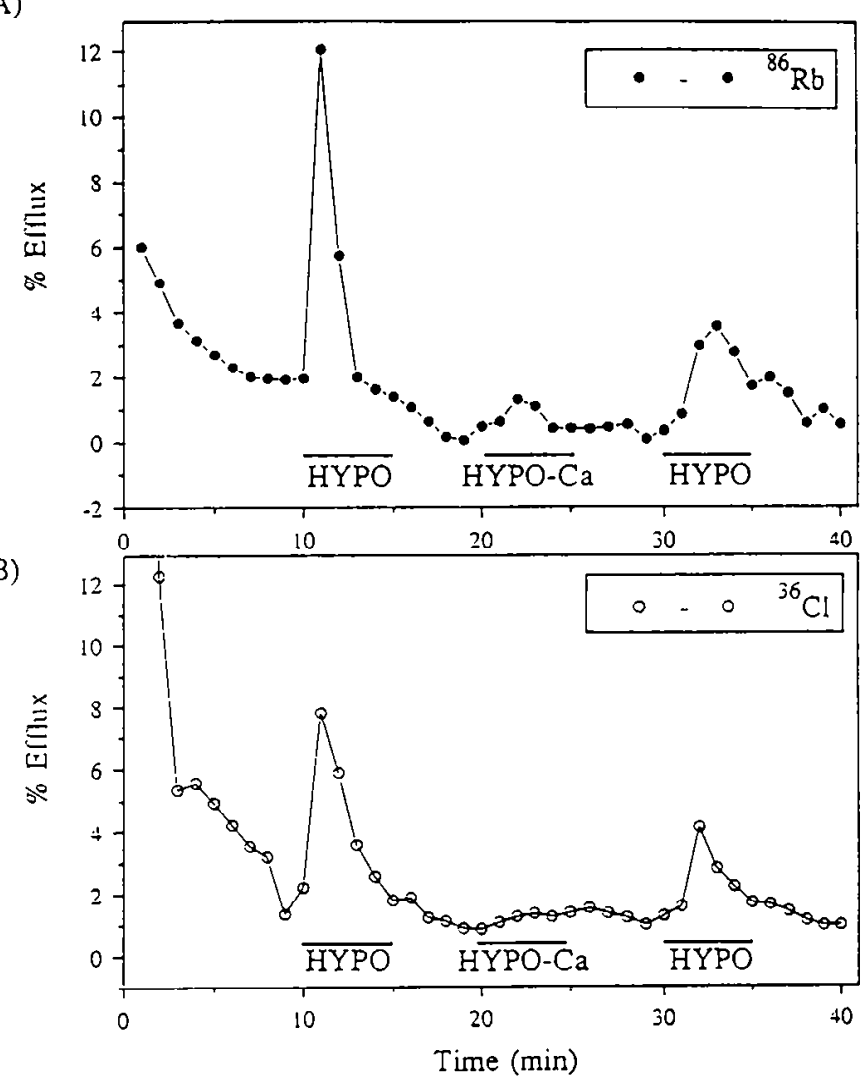

Figure 7. $A$, Hypotonic media-induced release of ${ }^{86} \mathrm{Rb}^{+}$(a marker for $\mathrm{K}$ - transport) and ${ }^{36} \mathrm{Cl}^{-}(B)$. Astrocytes were loaded for $2 \mathrm{hr}$ with 40 $\mu \mathrm{Ci}$ of the appropriate radionuclide and then transferred to a perfusion chamber and perfused with the appropriate buffers at $1 \mathrm{ml} / \mathrm{min}$. The perfusate was collected at $1 \mathrm{~min}$ intervals using a fraction collector, and the radioactivity in each sample determined by liquid scintillation counting. The data are expressed as a percentage of the remaining label left in the cell at cach time point (sce Materials and Methods). Exposure to hypotonic media caused the release of ${ }^{86} \mathrm{Rb}^{+}$and ${ }^{36} \mathrm{Cl}-$ ( first and third exposures), while removal of extracellular calcium abolished the hypotonic-induced release of ${ }^{80} \mathrm{Rb}^{+}$and ${ }^{36} \mathrm{Cl}^{-}$(middle exposures).

(Fig. 6B, upper trace): first, a normal transient increase in $\left[\mathrm{Ca}^{2+}\right]_{i}$; second, a rapid return toward baseline levels; and a third phase where before $\left[\mathrm{Ca}^{2+}\right]$, reached baseline an increase to a sustained plateau was observed. We had expected to see a smaller sustained plateau with nimodipine since ${ }^{45} \mathrm{Ca}^{2+}$ uptake studies showed that nimodipine was capable of blocking $60 \%$ of swelling-induced calcium influx. However, the fall-off of the initial peak of $\left[\mathrm{Ca}^{2+}\right]_{i}$ was always faster with nimodipine and the area under the curve within the first $50 \mathrm{sec}$ after exposure to hypotonic solution was about one-third that in the absence of nimodipine (seen in five experiments). When control cells were exposed to isotonic media minus calcium (no extracellular calcium present plus $50 \mu \mathrm{M}$ EGTA to chelate any calcium), or isotonic medium plus $1 \mu \mathrm{M}$ nimodipine, the basal $\left[\mathrm{Ca}^{2+}\right]_{i}$ level did not appreciably change over $5 \mathrm{~min}$ (data not shown).

Effects of $\mathrm{Ca}^{2+}$ on efflux of $\mathrm{K}^{+}$and $\mathrm{Cl}^{-}$. Astrocytes, like most vertebrate cell types, accomplish volume regulation after hypotonic-induced swelling by releasing $\mathrm{K}^{+}$and $\mathrm{Cl}^{-}$(Kimelberg and Frangakis, 1985). Since the removal of extracellular calcium abolished volume regulation, and volume regulation is accomplished by the release of ions, then it follows that the removal of extracellular calcium should also abolish ion release. We 

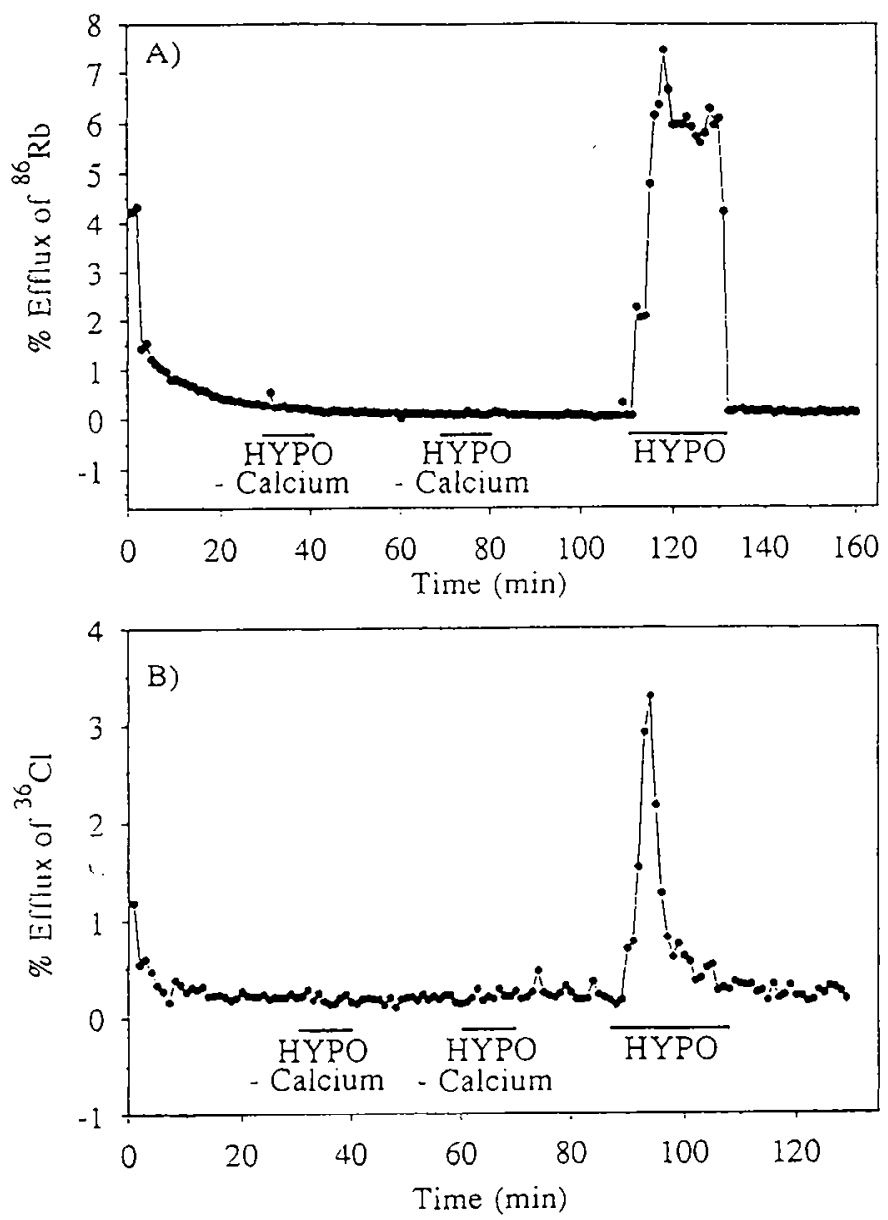

Figure 8. Astrocytes were loaded for $2 \mathrm{hr}$ with $100 \mu \mathrm{Ci}$ of the appropriate radionuclide as in Figure $7: A,{ }^{\text {x6 }} \mathrm{Rb}^{+} ; B,{ }^{36} \mathrm{Cl}^{-}$. Efflux was also measured as in Figure 7 except that the order of addition varied such that the first two exposures were to hypotonic media without $\mathrm{Ca}^{2}$ and were then followed by an exposure to hypotonic medium with normal $\mathrm{Ca}^{2+}$. Cells were exposed to isotonic solutions containing normal $\mathrm{Ca}^{2+}$ between the exposures to hypotonic media.

examined the effect of removing extracellular calcium on swelling-induced ${ }^{86} \mathrm{Rb}^{+}$efflux (using ${ }^{86} \mathrm{Rb}$ as a tracer for $\mathrm{K}+$ transport) and ${ }^{36} \mathrm{Cl}$ efflux. Astrocytes were loaded for $2 \mathrm{hr}$ with 40 $\mu \mathrm{Ci}$ of ${ }^{86} \mathrm{Rb}^{+}$or ${ }^{36} \mathrm{Cl}$. Figure 7 shows that removal of extracellular calcium abolished the swelling-induced ${ }^{86} \mathrm{Rb}^{+}(A)$ and ${ }^{36} \mathrm{Cl}^{-}(B)$ efflux (middle responses). Calcium-dependent $\mathrm{K}^{+}$efflux may thus occur through calcium-activated potassium channels that are known to exist in astrocytes (Quandt and MacVicar, 1986) and calcium-dependent chloride efflux through calciumactivated $\mathrm{Cl}^{-}$channels that have been seen in other cell types (Hoffmann et al., 1984; Pierce and Politis, 1990). The reason for the smaller third responses compared to the first response is unlikely to be due to loss of intracellular ${ }^{86} \mathrm{Rb}+$ or ${ }^{36} \mathrm{Cl} \cdot$ since the efflux is expressed as a percentage of the amount left at cach time point, which should correct for the progressively decreasing specific activity of ${ }^{86} \mathrm{Rb}^{+}$and ${ }^{36} \mathrm{Cl}^{-}$inside the cell. One possibility is that there may be a "desensitization" of $\mathrm{K}^{+}$channcls or their regulatory processes for the third response, a residual compartmentation for $\mathrm{K}^{+}$and $\mathrm{Cl}^{-}$that is relatively insensitive to hypotonic-induced release, or that subsequent exposures cause less swelling due to incomplete reaccumulation of the solutes lost during RVD. We thus employed a different order of addition, as shown in Figure 8: exposing the cells preloaded with ${ }^{86} \mathrm{Rb}^{+}$or ${ }^{36} \mathrm{Cl}^{-}$to $\mathrm{Ca}^{2+}$-free media first. For these experiments astrocytes wcre loaded for $2 \mathrm{hr}$ with increased radioactivity, namely, $100 \mu \mathrm{Ci}$ of ${ }^{86} \mathrm{Rb}^{+}$or ${ }^{36} \mathrm{Cl}^{-}$to increase the number of counts in the cells. As can be seen, no increased efflux of either ${ }^{86} \mathrm{Rb}^{4}$ or ${ }^{36} \mathrm{Cl}$ " was observed when astrocytes were first exposed for two 10 min periods to hypotonic media minus $\mathrm{Ca}^{2+}$ buffer, between exposures to $\mathrm{Ca}^{2+}$-containing isotonic medium. A large efflux was, however, observed upon a third exposure to hypotonic media with normal extracellular calcium present.

Effects of $\mathrm{Ca}^{2+}$ on efflux of aspartate and laurine. Primary astrocyte cultures swollen by exposing them to hypotonic media release both preloaded and endogenous glutamate, aspartate, and taurine (Pasantes-Morales and Schousboc, 1988; Kimelberg et al., 1990b; Pasantes-Morales et al., 1990). We therefore wished to determine how such release was also affected by the removal of medium calcium. Figure $9 A$ shows efflux of preloaded ${ }^{3} \mathrm{H}$ D-aspartate (a nonmetabolizable analog of glutamate) in response to successive exposures to hypotonic media (minus 50 mм $\mathrm{NaCl}$ ). When astrocytes were exposed to hypotonic media, they initially showed a peak release of approximatcly $5-8 \%$ of their labeled aspartate pool. Subsequent hypotonic challenges consistently showed a decrease in this peak release. The reasons behind this apparent desensitization have not yet been explored (see comments on ${ }^{86} \mathrm{Rb}^{+}$and ${ }^{36} \mathrm{Cl}^{-}$efflux above). However, unlike the efflux of ${ }^{86} \mathrm{Rb}^{+}$and ${ }^{36} \mathrm{Cl}^{-}$, the removal of extracellular calcium (third response) had no effect on the release of ${ }^{3} \mathrm{H}$ D-aspartate. Since omission of calcium results only in a nominal calcium-free buffer, 2 mM EGTA was added to the calcium-free buffers to chelate any extracellular calcium present, and the effect of this type of solution is shown in Figure $9 B$. The presence of EGTA had no obvious effect on the hypotonic media-induced release, but there was a slow rise in the baseline efflux of ${ }^{3} \mathrm{H}$ D-aspartate when the cells were exposed to isotonic media without $\mathrm{Ca}^{2+}$ plus EGTA (third exposurc). We have also seen a slow increase in cell volume as measured by the impedance method when the astrocytes wcrc cxposed to isotonic media without $\mathrm{Ca}^{2+}$, which further increased when EGTA was also present (data not shown). This finding supports the work by Olson et al. (1990), who showed that astrocyte cell volume was increased approximately $16 \%$ after exposure to isosmotic buffer containing $\mathrm{Ca}^{2}+$ but additionally EDTA, and the work of Martin et al. (1989), who showed increased release of ${ }^{3} \mathrm{H}$-taurine in isosmotic $\mathrm{Ca}^{2}$-free EGTA-containing medium. One further possibility was that the increase in $\left[\mathrm{Ca}^{2+}\right]$, observed using fura-2 during hypotonic exposure in calcium-free media, presumably due to release from intracellular stores (see Fig. $6 B$ ), was sufficient to support ${ }^{3} \mathrm{H}$-D-aspartate release. In Figure $9 C$, astrocytes were loaded with $25 \mu \mathrm{M}$ quin-2 for $1 \mathrm{hr}$ to buffer intracellular calcium, with EGTA added to all calcium-free buffers. Again, this did not appear to affect the release of ${ }^{3} \mathrm{H}$-D-aspartate due to exposurc to hypotonic media. The removal of extracellular calcium and/ or the buffering of intracellular calcium also did not affect hypotonic media-stimulated release of preloaded ${ }^{3} \mathrm{H}$-taurine (data not shown). Since RVD in astrocytes is dependent on extracellular calcium, these data suggest that amino acid release is not a necessary component for RVD to occur, although it is clearly a consequence of astrocytic swelling.

Since we had found that $1 \mathrm{~mm}$ quinine, which is known to block calcium-activated $\mathrm{K}$ + channels, abolished volume regulation (sce Fig. $2 B$ ), we also tested its effect on ${ }^{86} \mathrm{Rb}^{+}$and ${ }^{3} \mathrm{H}$ - 

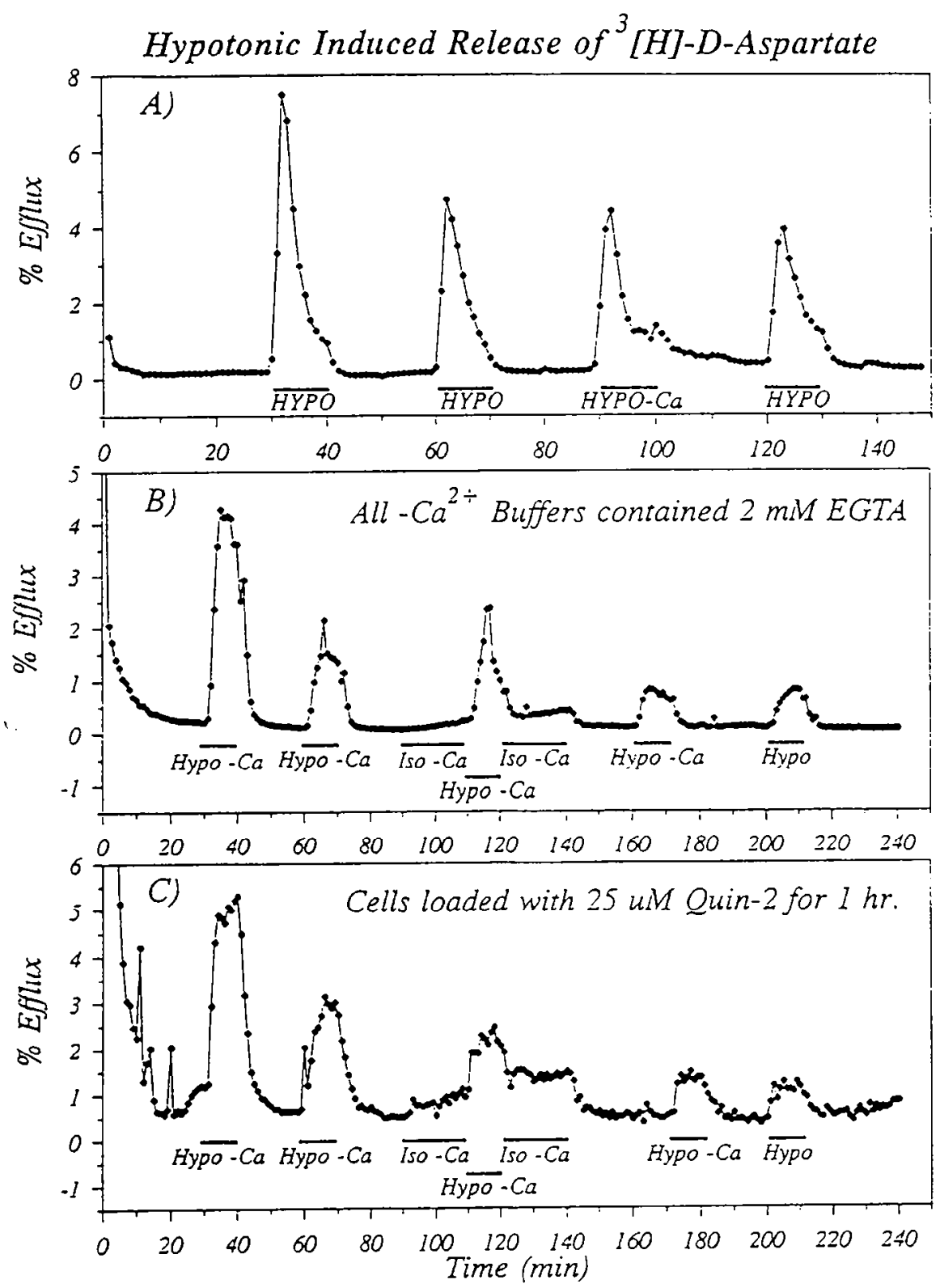

Figure 9. Calcium independence of hypotonic-induced efflux of ${ }^{3} \mathrm{H}$-D-aspartate from primary astrocyte cultures. The cells, grown on cell support film, were incubated overnight with 0.4 $\mu \mathrm{Ci}$ of ${ }^{3} \mathrm{H}$-aspartic acid. $A$, The third exposure shows that removing extracellular calcium did not affect the hyposmotic (minus $50 \mathrm{~mm} \mathrm{NaCl}$ )-induced release of ${ }^{3} \mathrm{H}$-D-aspartate. $B$, Extracellular calcium was removed and 2 mm EGTA was also added to all hypotonic solutions to buffer any extracellular calcium that may have been present. Also, for the third response, cells were pre- and postexposed to an isotonic minus $\mathrm{Ca}^{2+}$ plus 2 mM EGTA solution. $C$, Extracellular calcium was removed and buffered with 2 mM EGTA, as in $B$, and the cells were also loaded with $25 \mu \mathrm{M}$ quin-2 to buffer any intracellular free calcium.
D-aspartate release. As seen in Figure $10 \mathrm{~A}, 1 \mathrm{~mm}$ quinine blocked the swelling-induced ${ }^{86} \mathrm{Rb}^{+}$release, supporting the role of a calcium-activated $\mathrm{K}^{+}$efflux during astrocyte volume regulation, but had no effect on ${ }^{3} \mathrm{H}$-D-aspartate release (Fig. 10B). This further supports our finding that amino acid release is not necessary for astrocyte volume regulation. The experiments in Figure 10 was also performed as a control for the necessary design of the volume measurement experiments using the resistance method, which requires the same ionic concentrations between iso- and hyposmotic solutions. The hypotonic buffers were made as usual, by the removal of $50 \mathrm{~mm} \mathrm{NaCl}$, but the isotonic control was made by adding $100 \mathrm{~mm}$ sucrose to the hypotonic buffer (as was done in the electrical resistance measurements). This experimental design allows us to maintain ionic concentrations (namely, $\mathrm{NaCl}$ ) while altering the tonicity of the solutions, and thus shows that the release of amino acids and ions is swelling dependent and not due to a lowering of the extracellular $\mathrm{Na}^{+}$ or $\mathrm{Cl}$ concentrations.

\section{Discussion}

Requirement of $\mathrm{Ca}^{2+}$ for volume regulation. Upon exposure to hypotonic solution, astrocytes in primary culture swell to a peak volume and then undergo RVD. A requirement for $\mathrm{Ca}^{2+}$ in controlling the RVD response has been shown in a number of cell types (Pierce and Politis, 1990). The data presented in this study indicate that hypotonic-induced cell volume regulation in astrocytes is dependent on extracellular calcium, since when calcium was removed from the extracellular medium astrocytes failed to exhibit RVD. Conversely, if calcium was added to swollen astrocytes in calcium-free media, volume regulation was almost immediately initiated.

McCarty and O'Neil (1990) reported that volume regulation after swelling was highly dependent on extracellular calcium in rabbit proximal straight tubule. They reported a half-maximal inhibition of RVD at $100 \mu \mathrm{M} \mathrm{CaCl}_{2}$, as we found for astrocyte volume regulation. They also reported that if RVD was initially 

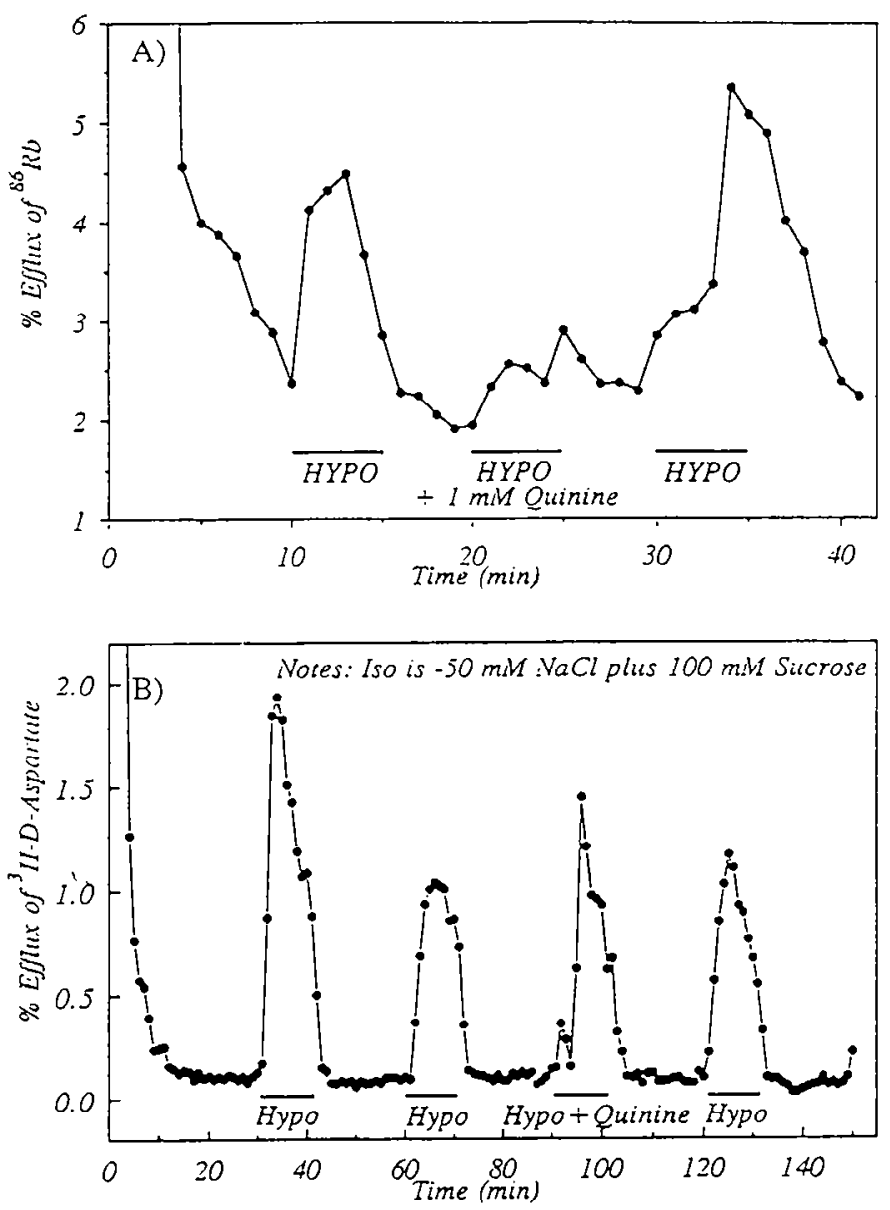

Figure 10. Effect of quinine on ${ }^{86} \mathrm{Rb}^{+}$and ${ }^{3} \mathrm{H}$-D-aspartate release. $A$, The addition of $1 \mathrm{~mm}$ quinine blocked hypotonic-induced ${ }^{86} \mathrm{Rb}$. release. $B$, The addition of $1 \mathrm{~mm}$ quinine did not affect hypotonic media-induced ${ }^{3} \mathrm{H}$-D-aspartate release. The hypotonic buffer was made by removing 50 $\mathrm{mm} \mathrm{NaCl}$, while the isotonic control was made by adding $100 \mathrm{~mm}$ sucrose to the hypotonic buffer (as was done in the electrical resistance measurements).

blocked by reducing $\left[\mathrm{Ca}^{2+}\right]$, or by the addition of verapamil during hypotonic swelling, volume regulation could only be restored by subsequently inducing calcium entry within the first $1 \mathrm{~min}$ or less of exposure to hypotonic media. They suggested a "calcium window" of $<1$ min, during which RVD is sensitive to $\mathrm{Ca}^{2+}$, and after that the $\mathrm{Ca}^{2+}$-sensitive mechanisms for RVD undergo inactivation. We have found no such "calcium window" in astrocytes, as adding $1 \mathrm{mM} \mathrm{CaCl}_{2}$ up to $10 \mathrm{~min}$ after exposure to hypotonic media minus calcium causes immediate initiation of RVD (data not shown).

Swelling-activated $\mathrm{Ca}^{2+}$ entry and rise in $\left.\mathrm{CCa}^{2+}\right]_{1}$. Either extracellular or intracellular $\mathrm{Ca}^{2+}$ may be the signal that activates RVD following exposure to hypotonic solutions. In all cell types that report a calcium dependence of RVD, except for Ehrlich ascites tumor cells (Hoffmann et al., 1984) and lymphocytes (Grinstein et al., 1982), the source of calcium is cxtraccllular, that is, requiring $\mathrm{Ca}^{2}+$ entry to activate RVD. Swelling-induced calcium uptake has been reported in renal proximal tubule cells (McCarty and O'Neil, 199 la,b), canine kidney cells (Rothstein and Mack, 1992), toad urinary bladder (Wong and Chase, 1986), and Necturus gallbladder (Foskett and Spring, 1985). Since we found that swelling-induced entry of ${ }^{45} \mathrm{Ca}^{2+}$ in astrocytes was partially blocked by the dihydropyridine $\mathrm{Ca}^{2+}$-channel antagonist nimodipine, this indicates that one route of $\mathrm{Ca}^{2+}$ entry is through voltage-gated L-type channels. In previous electrophysiology expcriments, we showed that exposing astrocytes to hypotonic solutions caused marked membrane potential depolarizations proportional to the degree of hypotonicity ( $\mathrm{Ki}$ melberg and O'Connor, 1988), as also seen in other cells (Ubl et al., 1988). A voltage-sensitive $\mathrm{Ca}^{2+}$ channel, resembling the L-type channel, has been described in cortical astrocytes in isosmotic conditions when the cells were treated with dibutyryl cAMP (MacVicar, 1984, 1987; Barres et al., 1988, 1990; MacVicar and Tse, 1988). It is therefore of interest that we observed L-channel activity in swollen astrocytes that had not been treated with cAMP. Possibly, swelling activates the normally quiescent channels perhaps by increasing intracellular cAMP, as has been observed in other cells (Watson, 1989, 1990; Baquet et al., 1991). The depolarization observed in media made hypotonic by removal of $100 \mathrm{mOsm}$, as routinely used in this study, would be around $50 \mathrm{mV}$, reducing the membrane potential to approximately $-20 \mathrm{mV}$, which would be sufficient to begin to open the voltage-sensitive calcium channels. Also we found that depolarizing the cells with raised $\mathrm{K}^{+}$in the medium ( 50 and $100 \mathrm{~mm}$ ) led to an increase in the fura signal (data not shown).

However, since only $60 \%$ of the ${ }^{45} \mathrm{Ca}^{2+}$ entry was inhibited by nimodipine, other pathways must exist. One possible route for calcium entry could be via the electrogenic sodium-calcium $3 \mathrm{Na}^{+} / \mathrm{Ca}^{2+}$ exchange system working in the reverse mode due to intracellular $\mathrm{Ca}^{2+}$ depletion and $\mathrm{Na}^{+}$gain as seen in astrocytes after exposure to low $\mathrm{Ca}^{2+}$ mimicking the "calcium paradox" phenomenon (Kim-Lee et al., 1992), and cell membrane depolarization. Since swelling increases release of intracellular $\mathrm{Ca}^{2+}$, and thus presumably depletes internal stores, and this is known to lead to activation of $\mathrm{Ca}^{2+}$ channels, some of the increased ${ }^{45} \mathrm{Ca}^{2+}$ influx could also be via such a mechanism. Also, increased ${ }^{45} \mathrm{Ca}^{2+}$ uptake could be via $\mathrm{Ca}^{2+} / \mathrm{Ca}^{2+}$ exchange.

$A$ further additional route for swelling-activated $\mathrm{Ca}^{2}$, entry could be through strctch-activated channels (SACs) in the plasma membrane. Cation-specific and $\mathrm{Ca}^{2+}$-permeable channels sensitive to membrane stretch have been described in salamander choroid plexus epithelium (Christensen, 1987), porcine vascular endothelium (Lansman et al., 1987), renal proximal tubules (Filipovic and Sackin, 1991), Xenopus oocytes (Yang and Sachs, 1990), and murine skeletal myotubes (Franco and Lansman, 1990a,b). A SAC permeable to calcium has been reported in human retinal glial cells (Puro, 1991), but it was not determined if an increase in cell volume activated this channel. In whole-cell recordings from cultured astrocytes (Kimelberg et al., 1990a) nonspecific cation currents were seen upon exposure to hypotonic solutions, which are likely responsible for the marked depolarization of the membrane potential seen in swollen astrocytes (Kimelberg and O'Connor, 1988; Kimelberg and Kettenmann, 1990). These currents could include $\mathrm{Ca}^{2+}$, but this was not determined. Further characterization of stretch-activated ion channels is necessary to elucidate their role in $\mathrm{Ca}^{2+}$ entry and $\mathrm{K}^{+}$and $\mathrm{Cl}^{-}$efflux during volume regulation.

The extracellular calcium required to activate $\mathrm{RVD}$ is assumed to act as a source for the rise in $\left[\mathrm{Ca}^{2+}\right]_{i}$. A swellinginduced increase in calcium influx, leading to a rise in intracellular calcium, has been reported in a number of cell types (Wong and Chase, 1986; Hazama and Okada, 1990; Rothstein and Mack, 1990; Wong et al., 1990). In our studies it was found that swelling in the presence of normal calcium was associated with an increase in intracellular free calcium concentration that 
was characterized by a biphasic response. Using fura- 2 we found that hypotonic media-induced swelling led to an initial transient increase in free $\left[\mathrm{Ca}^{2+}\right]_{t}$, which was due to releasc of $\mathrm{Ca}^{2+}$ from intracellular stores since removal of $\left[\mathrm{Ca}^{2+}\right]_{e}$ did not affect it. This release is stimulated by IP compounds and $\mathrm{IP}_{3}$ increases have been reported to occur during RVD, at least in Ehrlich ascites cells (Hoffman and Kolb, 1992). In the absence of [Ca $\left.{ }^{2}{ }^{2}\right]_{e}$, $\left[\mathrm{Ca}^{2+}\right]$, rapidly returned to baseline values, without the sustained plateau seen in the presence of normal $\left[\mathrm{Ca}^{2+}\right]_{e}$. The sustained increase above baseline also appears to be partly due to $\mathrm{Ca}^{2+}$ entry since nimodipine, which blocked approximately $60 \%$ of the swelling-induced ${ }^{45} \mathrm{Ca}^{2+}$ entry, also caused a more rapid decline of the initial transient and a partial decrease of the sustained plateau (Fig. 7). That nimodipine did not abolish the plateau, as was seen upon removal of $\left[\mathrm{Ca}^{2} \cdot\right]_{\ell}$, might be expected as nimodipine did not block all calcium entry, as measured by influx of ${ }^{45} \mathrm{Ca}^{2+}$.

Release of ions. Volume regulation under hypotonic conditions is often due to the cellular loss of $\mathrm{KCl}$ with water. Both electroneutral cotransporters and electroconductive channels may be responsible for volume-sensitive $\mathrm{KCl}$ fluxes (Hoffmann and Simonsen, 1986). In some cells the $\mathrm{K}^{+}$and $\mathrm{Cl}^{-}$conductances are separate, for example, in human lymphocytes (Grinstein et al., 1982), frog urinary bladder (Davis and Finn, 1987), human intestinal epithelial cells (Hazama and Okada, 1988), Ehrlich ascites cells (Hoffmann et al., 1984), and Chinese hamster ovary cells (Sarkadi et al., 1984). In other cell types, like Necturus gallbladder cpithclial cells (Larson and Spring, 1984) and most red blood cells (Pierce and Politis, 1990), $\mathrm{K}^{+}$movements are completely $\mathrm{Cl}^{-}$dependent, indicating cotransport.

Since the RVD process in astrocytes appeared completely sensitive to extracellular calcium, the possibility that volumesensitive $\mathrm{KCl}$ efflux was sensitive to calcium was examined. The data indicated that release of both $\mathrm{K}^{+}$and $\mathrm{Cl}$ in $\mathrm{RVD}$ was dependent on $\left[\mathrm{Ca}^{2+}\right]_{e}$. Calcium-activated $\mathrm{K}^{+}$channels have been reported in astrocytes (Quandt and MacVicar, 1986; Barres et al., 1990) and in astrocytic retinal Müller cclls (Puro et al., 1991). These channels are activated by membrane depolarization and increases in intracellular $\mathrm{Ca}^{2+}$ concentration. A role for these channels in RVD was also supported by the finding that quinine, a known blocker of $\mathrm{Ca}^{2}+$-activated $\mathrm{K}^{+}$channels, also blocked the swelling-induced release of ${ }^{86} \mathrm{Rb}^{+}$.

There is more evidence that activation of volume regulatory $\mathrm{K}^{+}$transport systems are controlled by cytosolic calcium than for $\mathrm{Cl}$ (Grinstein et al., 1982; Foskett and Spring, 1985; Hoffmann et al., 1986; Hazama and Okada, 1988; Pierce and Politis, 1990). Volume regulatory $\mathrm{Cl}^{-}$conductances are activated in response to hyposmotic stress in $\mathrm{Ca}^{2+}$-depleted lymphocytes (Grinstein et al., 1982) and $\mathrm{Ca}^{2+}$-depleted human gut epithelial cells (Hazama and Okada, 1988). However, $\mathrm{Ca}^{2+}$-activated $\mathrm{Cl}^{-}$ transport pathways have been reported in several cell types, including Xenopus oocytes (Miledi and Parker, 1984), trachcal epithelial cells (Frizzell et al., 1986), neurons (Mayer, 1985), and several other cell types (Hoffmann and Simonsen, 1989). Also, Hoffmann et al. (1986) showed that A23187, a calcium ionophore, caused increased $\mathrm{Cl}$ loss from hyposmotically stressed Ehrlich ascites cells. RVD involving $\mathrm{Cl}^{-\cdots}$ requires that there is adequate intracellular $\mathrm{Cl}^{-}$. While $\mathrm{Cl}$ in cultured astrocytes is at 30-40 mM (Kimelberg, 1981), glial cells in guinea pig olfactory cortex showed a passive $\mathrm{Cl}$ distribution (Ballanyi et al., 1987). Perhaps in vivo, $\mathrm{HCO}_{3}{ }^{-}$efflux, or some other anion, also contributes to RVD in astrocytes.
Release of amino acids. Release of taurine, glutamate, aspartate, and other amino acids has been shown to occur during RVD in a number of vertebrate and invertebrate cell types (Gilles et al., 1991). Pasantes-Morales and Schousboe (1989) showed a hypotonic media-induced release of radiolabeled and endogenous taurine, and Kimelberg et al. (1990b) reported that exposurc of primary astrocytc cultures to hypotonic media led to release of label after cells had been allowed to accumulate ${ }^{3} \mathrm{H}$-L-glutamate, ${ }^{3} \mathrm{H}$-D-aspartate, or ${ }^{3} \mathrm{H}$-taurine, as well as release of endogenous glutamate and taurine as measured by HPLC. These findings led us (Kimelberg et al., 1990b) to suggest that swollen astrocytes may be an additional source of release for L-glutamate and L-aspartate, which could contribute to excitotoxic, amino acid-induced neuronal injury (Choi, 1988), since astrocytic swelling is an early event in a number of pathological states including traumatic head injury and cerebral ischemia (see reviews by Kimelberg and Ransom, 1986, and Kimelberg, 1992). Whilc hypotonic conditions are only encountered in vivo in cases involving kidney failure, and astrocytic edema is likely due to a variety of other causcs such as high [K+] or glutamate (Kimelberg, 1991, 1992; Kimelberg et al., 1993), we assume that the same degree of swelling will result in activation of the same processes. However, hyponatremia is often a problem in head-injured patients due to systemic effects of the injury. Resolution of astrocytic swelling on a time course of $1-2 \mathrm{hr}$, which is about sixfold longer than RVD, has been described after experimental closed-head injury in cats (Barron et al., 1988). Even under conditions of normal neuronal activity, accumulation of $\mathrm{K}^{+}$as $\mathrm{KCl}$ with $\mathrm{H}_{2} \mathrm{O}$ and/or uptake of transmitters, such as glutamate, with $\mathrm{Na}^{+}$, may be compensated for by $\mathrm{Ca}^{2+}$-activated release of $\mathrm{KCl}$ to maintain normal cell volume.

We also examined whether the hypotonic-induced release of amino acids contributed to the RVD process in astrocytes, as has been suggested for other cell types (Law, 1991) and as has been suggested for taurine release in the brain (Thurston et al., 1980; Pasanatcs-Morales and Schousboe, 1988). Since RVD in our astrocytes was highly dependent on $\left[\mathrm{Ca}^{2+}\right]_{c}$, then the release of amino acids should also be sensitive to $\left[\mathrm{Ca}^{2+}\right]$, if such release contributes significantly to RVD. We found that removal of extracellular calcium and/or buffering of intracellular calcium had no effect on the swelling-induced release of ${ }^{3} \mathrm{H}$-D-aspartate (Fig. 9) or ${ }^{3} \mathrm{H}$-taurine (data not shown). Pasantes-Morales et al. (1990) have also reported that hypotonic-induced taurine release was unaffected by removal of extracellular calcium. Therefore, these data suggest that amino acid release during RVD, while occurring concomitantly, is not necessary for volume regulation in cultured astrocytes. One possible explanation is that because only $1-10 \%$ of the aspartate or glutamate pool is released during volume regulation, and because endogenous concentrations of these amino acids are quite low in the brain (Clarke et al., 1989), the release of aspartate or glutamate is not of a sufficient quantity to play an important role in volume regulation in astrocytes. Also, since taurine in the brain is approximately $2-5 \mathrm{mM}$, its role in volume regulation in situ has been questioned (Martin et al., 1990). Our data suggest that taurine does not contribute as an osmolyte even under marked hypotonic-induced swelling. However, in cultured astrocytes the apparent concentration of ${ }^{3} \mathrm{H}$-taurine is $50-80 \mathrm{~mm}$ (Kimelberg et al., 1990b), so its apparent lack of contribution to RVD in cultured cells is surprising. The swelling-induced, $\mathrm{Ca}^{2+}$-independent release of amino acids from astrocytes may contribute to the $\mathrm{Ca}^{2+}$-independent release of glutamate seen during ex- 
Figure 11. Possible roles of calcium involvement in volume regulation of astrocytes swollen by hypotonic media and different possible transport pathways for RVD. The sequence of events is suggested to occur as follows: astrocyte in hypotonic media $\rightarrow$ cell swelling due to water influx $\rightarrow$ membrane depolarization due to opening of nonspecific cation SACs $\rightarrow \mathrm{Ca}^{2}$ " entry predominantly via voltage-gated channels $\rightarrow$ increased free $\left[\mathrm{Ca}^{2+}\right] \rightarrow$ activation of $\mathrm{Ca}^{2+}$-dependent $\mathrm{K}^{+}$and $\mathrm{Cl}^{-}$channels $\rightarrow$ efflux of ions $\rightarrow$ volume decrease. See last section of Discussion for further details.

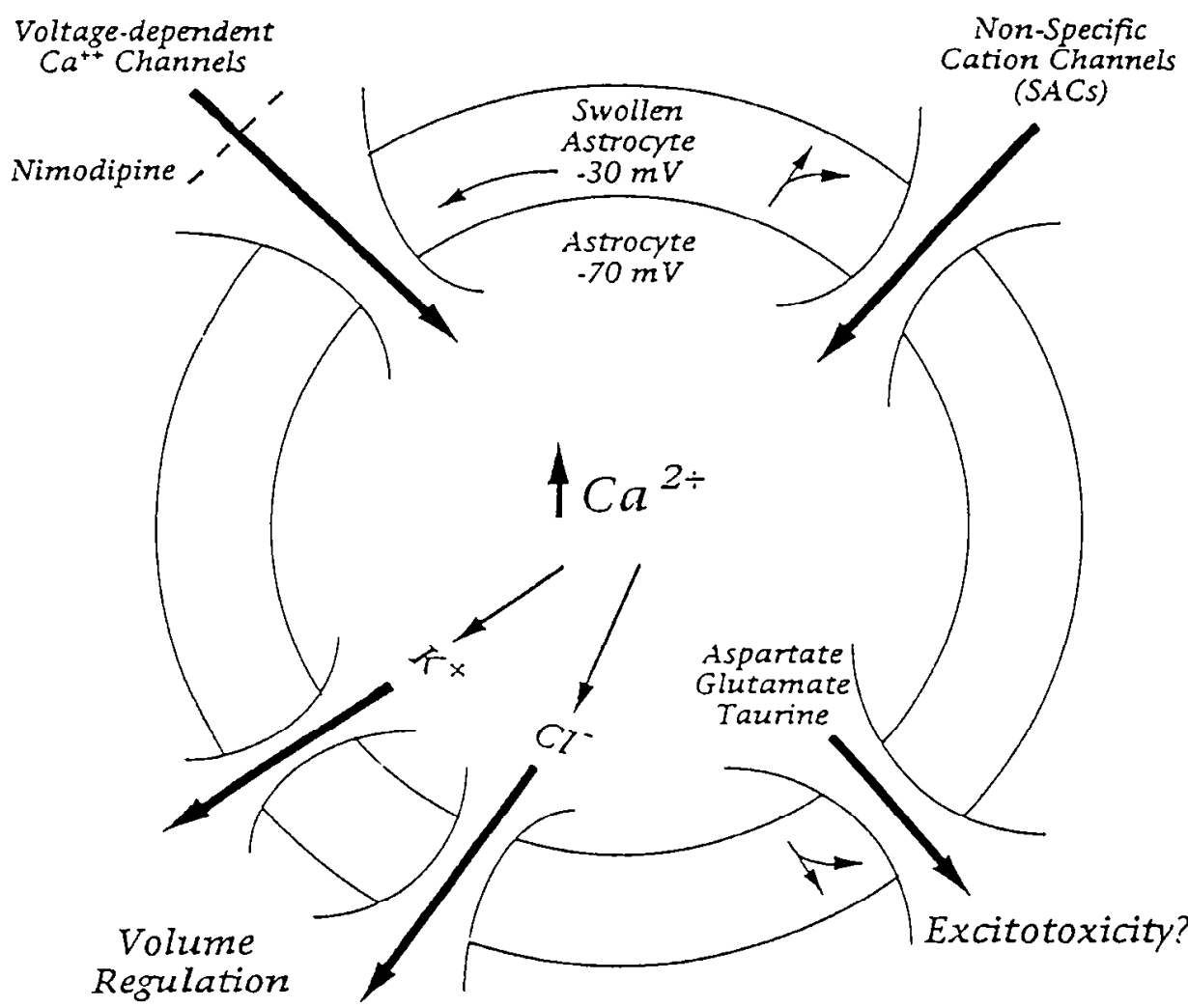

perimental ischemia in vivo, which comes later and is smaller than the initial $\mathrm{Ca}^{2+}$-dependent release (Katayama et al., 1991).

Model of the roles of $\mathrm{Ca}^{2+}$ in astrocyte $\mathrm{RVD}$. Figure 11 is a proposed model depicting the possible roles of calcium in initiation of RVD in astrocytes swollen by exposure to hypotonic medium. In this model, swelling of astrocytes due to exposurc to hypotonic media initially causes depolarization of the membrane potential, possibly through opening of nonspecific cation, swelling-activated channcls (SACs). This depolarization then activates voltage-sensitive $\mathrm{Ca}^{2+}$ channels, allowing entry of calcium into the cell, since this entry can be partially blocked by voltage-sensitive calcium channel blockers. Other routes of $\mathrm{Ca}^{2}+$ entry also probably occur. Release from intracellular stores also causes the free $\left[\mathrm{Ca}^{2+}\right]$, to increase transiently. However, it appears to be the sustained cntry of extracellular $\mathrm{Ca}^{2+}$ that opens $\mathrm{Ca}^{2+}$-dependent $\mathrm{K}^{+}$channels and $\mathrm{Cl}^{-}$channels that allow $\mathrm{KCl}$ to leave the cell. Amino acids are also released, but by a mechanism that does not involve $\mathrm{Ca}^{2}+$ and therefore may be activated directly by tension in the membrane, or perhaps by the depolarization or by involvement of second messenger changes such as cAMP or phosphatidylinositol products (Watson, 1989, 1990; Baquet et al., 1991; Hoffmann and Kolb, 1991). The swellinginduced release of amino acids is inhibited by several anion transport blockers and is $\mathrm{Na}^{+}$independent, and in the case of glutamate is unaffected by glutamate uptake blockers, which argue against release being due to reversal of the uptake system (Kimelberg et al., 1990b). The release of intracellular ions, along with osmotically obligated water, results in the astrocytes' volume regulating back close to their initial volume.

\section{References}

Albrecht J, Lazarewicz JW (1990) Acute hepatic encephalopathy decreases potassium-evoked calcium uptake in astrocytes but not in synaptosomes of the rat. Neurosci Lett 111:321-324.
Ballanyi K, Grafe P (1988) Cell volume regulation in the nervous system. Renal Physiol Biochem 11:142-157.

Ballanyi K, Grafe P, ten Bruggencate G (1987) Ion activities and potassium uptake mechanisms of glial cells in guinea-pigs olfactory cortex slices. J Physiol (Lond) 382:159-174.

Banderali U, Roy G (1992) Activation of $\mathrm{K}^{\cdot}$ and $\mathrm{Cl}$ channels in MDCK cells during volume regulation in hypotonic media. J Membr Biol 126:219-234.

Baquet A, Meijer AJ, Hue L (1991) Hepatocyte swelling increases inositol 1,4,5-trisphosphate, calcium and cyclic AMP concentration but antagonizes phosphorylase activation by $\mathrm{Ca}^{2+}$-dependent hormones. FEBS Lett 278:103-106.

Barres BA, Chun LL, Corey DP (1988) Ion channel expression by white matter glia. I. Type 2 astrocytes and oligodendrocytes. Glia $1: 10-30$.

Barres BA, Chun LLY, Corey DP (1989) Calcium current in cortical astrocytes: induction by cAMP and neurotransmitters and permissive effect of serum factors. J Neurosci 9:3169-3175.

Barres BA, Chun LLY, Corcy DP (1990) Ion channels in vertebrate glia. Annu Rev Neurosci 13:441-474.

Barron KD, Dentinger MP, Kimelberg HK, Nelson LR, Bourke RS, Keegan S, Mankes R, Cragoe EJ Jr (1988) Ultrastructural features of a brain injury model in cat. I. Vascular and ncuroglial changes and the prevention of astroglial swelling by a fluorenyl (aryloxy) alkanoic acid derivative (L-644, 711). Acta Neuropathol (Berl) 75:295-307.

Cala PM, Mandel LJ, Murphy E (1986) Volume regulation by $\mathrm{Am}$ phiuma red blood cells: cytosolic free $\mathrm{Ca}$ and alkali metal- $\mathrm{H}$ exchange. Am J Physiol 250:C423-C429.

Chamberlin ME, Strange K (1989) Anisosmotic cell volume regulation: a comparative view. Am J Physiol 257:C159-C173.

Choi DW (1988) Glutamate neurotoxicity and diseases of the nervous system. Neuron 1:623-634.

Christensen $\mathrm{O}$ (1987) Mediation of cell volume regulation by $\mathrm{Ca}^{2+}$ influx through stretch-activated channels. Nature 330:66-68.

Clarke DD, Lajtha AL, Maker HS (1989) Intermediary metabolism. In: Basic neurochemistry, Vol 4 (Siegel G, Agranoff B, Albers RW, Molinoff P, eds), pp 541-564. New York: Raven.

Cobbold PH, Rink TJ (1987) Fluorescence and bioluminescence measurement of cytoplasmic free calcium. Biochem J 248:313-328.

Davis CW, Finn AL (1987) Interactions of sodium transport, cell 
volume, and calcium in frog urinary bladder. J Gen Physiol 89:687702.

Eveloff JL, Warnock DG (1987) Activation of ion transport systems during cell volume regulation. Am J Physiol 252:FI-F10.

Filipovic D, Sackin H (1991) A calcium-permeable stretch-activated cation channel in renal proximal tubule. Am J Physiol 260:F119F129.

Foskett JK, Melvin JE (1989) Activation of salivary secretion: coupling of cell volume and $\left[\mathrm{Ca}^{2+}\right.$, in single cells. Science $244: 1582-$ 1585.

Foskett JK, Spring KR (1985) Involvement of calcium and cytoskeleton in gallbladder epithelial cell volume regulation. Am J Physiol 248:C27-C 36.

Franco A Jr, Lansman JB (1990a) Calcium entry through stretchinactivated ion channels in $m d x$ myotubes. Nature 344:670-673.

Franco A Jr, Lansman JB (1990b) Stretch-sensitive channels in developing muscle cells from a mouse cell line. J Physiol (Lond) 427: $361-380$.

Frangakis MV, Kimelberg HK (1984) Dissociation of neonatal rat brain by dispase for preparation of primary astrocyte cultures. Neurochem Res 9:1689-1698.

Frizzell RA, Rechkemmer G, Shoemaker RL (1986) Altered regulation of airway epithelial cell chloride channels in cystic fibrosis. Science 233:558-560.

Gilles R, Hoffmann EK, Bolis L, eds (1991) Advances in comparative and environmental physiology: volume and osmolality control in animal cells. Berlin: Springer.

Goldschmidt RC, Kimelberg HK (1989) Protein analysis of mammalian cells in monolayer culture using the bicinchoninic assay. Anal Biochem 177:41-45.

Grinstein S, Foskett JK (1990) Ionic mechanisms of cell volume regulation in leukocytes. Annu Rev Physiol 52:399-414.

Grinstein S, Dupre A, Rothstein A (1982) Volume regulation by human lymphocytes - role of calcium. J Gen Physiol 79:849-868.

Hazama A Okada Y (1988) $\mathrm{Ca}^{2+}$ sensitivity of volume regulatory $\mathrm{K}$ + and $\mathrm{Cl}^{-}$channels in cultured human cpithclial cells. J Physiol (Lond) 402:687-702.

Hazama A, Okada $Y$ (1990) Biphasic rises in cytosolic free $\mathrm{Ca}^{2+}$ in association with activation of $\mathrm{K}^{+}$and $\mathrm{Cl}^{-}$conductance during the regulatory volume decrease in cultured human epithelial cells. Pfluegers Arch 416:710-714.

Hoffmann EK, Kolb H-A (1991) Mechanisms of activation of regulatory volume responses after ccll swelling. In: Comparative and $\mathrm{cn}$ vironmental physiology, Vol 9 (Gilles R, Hoffmann EK, Bolis L, eds), pp 140-185. New York: Springer.

Hoffmann EK, Simonsen LO (1989) Membrane mechanisms in volume and pH regulation in vertebrate cells. Physiol Rev 69:31 5-382.

Hoffmann EK, Simonsen LO, Lambert IH (1984) Volume-induced increase of $\mathrm{K}^{+}$and $\mathrm{Cl}^{-}$permeabilities in Fhrlich ascites. Role of internal $\mathrm{Ca}^{2+}$. J Membr Biol 78:211-222.

Hoffmann EK, Simonsen LO, Lambert IH (1986) Separate, $\mathrm{Ca}^{2+}$ activated $\mathrm{K}^{+}$and $\mathrm{Cl}^{-}$transport pathways in Ehrlich ascites tumor cells. J Membr Biol 91:227-244.

Holtz. RW, Center RA, Frye RA (1982) Relationship between $\mathrm{Ca}^{2}$ + uptake and catecholamine excretion in primary dissociated cultures of adrenal medulla. J Neurochem 39:635-646.

Katayama Y, Kawamata T, Tamura T, Hovda DA, Becker DP, Tsubokawa T (1991) Calcium-dependent glutamate release concomitant with massive potassium flux during cerebral ischemia in vivo. Brain Res 558:136-140.

Kempski O, Chaussy L, Gross U, Zimmer M, Baethmann A (1983) Volume regulation and metabolism of suspended C6 glioma cells: an in vitro model to study cytotoxic brain edema. Brain Res 279:217228 .

Kimelberg HK (1981) Active accumulation and exchange transport of chloride in astroglial cells in culture. Biochem Biophys Acta 646: 179-184.

Kimelberg HK (1991) Swelling and volume control in brain astroglial cells. In: Comparative and environmental physiology, Vol 9 (Gilles R, Hoffmann EK, Bolis L, eds), pp 81-117. New York: Springer.

Kimelberg HK (1992) Astrocytic edema in CNS trauma. J Ncurotrauma 9:S71-S81.

Kimelberg HK, Frangakis MV (1985) Furosemide- and bumetanidescnsitive ion transport and volume control in primary astrocyte cultures from rat brain. Brain Res 361:125-134.
Kimelberg HK, Kettenmann H (1990) Swelling-induced changes in electrophysiological properties of cultured astrocytes and oligodendrocytes. I. Effects on membrane potentials, input impedance and cell-cell coupling. Brain Res 529:255-261.

Kimclberg HK, O'Connor E (1988) Swelling of astrocytes causes membrane potential depolarization. Glia 1:219-224.

Kimelberg HK, Ransom BR (1986) Physiological and pathological aspects of astrocytic swelling. In: Astrocytes, Vol 3 (Federoff S, Vernadakis A, eds), pp 129-166. Orlando, FL: Academic.

Kimelberg HK, Anderson E, Kettenmann H (1990a) Swelling-induced changes in electrophysiological properties of cultured astrocytes and oligodendrocytes. II. Whole-cell currents. Brain Res 529:262-268.

Kimclberg HK, Goderic SK, Higman S, Pang S, Waniewski RA (1990b) Swelling-induced release of glutamate, aspartate, and taurine from astrocyte cultures. J Neurosci 10:1583-1591.

Kimelherg HK, O'Connor ER, Sankar P, Keese C (1992) Methods for determination of cell volume in tissue culture. Can J Physiol Pharmacol [Suppl] 70:S323-S333.

Kimelberg HK, O'Connor ER, Kettenmann H (1993) Effects of swelling on glial cell function. In: Advances in comparative and environmental physiology, Vol 14 (Lang F, Haussinger D, eds), pp 157-186. Berlin: Springer.

Kim-Lee MH, Stokes BT, Yates AJ (1992) Reperfusion paradox: a novel mode of glial cell injury. Glia 5:56-64.

Lansman JB, Hallam TJ, Rink TJ (1987) Single stretch-activated ion channels in vascular endothelial cells as mechanotransducers? Nature 325:811-813.

Larson M, Spring KR (1984) Volume regulation by Necturus gallbladder: basolateral KCl exit. J Membr Biol 81:219-232.

Law RO (1991) Amino acids as volume-regulatory osmolytes in mammalian cells. Comp Biochem Physiol 99:263-277.

MacVicar BA (1984) Voltage-dependent calcium channels in glial cells. Science 226:1345-1347.

MacVicar BA (1987) Morphological differentiation of cultured astrocytes is blocked by cadmium or cobalt. Brain Res 420:175-177.

MacVicar BA, Tse FW (1988) Norepinephrine and cyclic adenosine $3^{\prime}: 5^{\prime}$-cyclic monophosphate enhance a nifedipine-sensitive calcium current in cultured rat astrocytes. Glia 1:359-365.

Martin DL, Madelian V, Shain W (1989) Spontaneous and $\beta$-adrenergic receptor-mediated taurine release from astroglial cells do not require extracellular calcium. J Neurosci Res 23:191-197.

Martin DL, Madelian V, Seligmann B, Shain W (1990) The role of osmotic pressurc and membrane potential in $\mathrm{K}^{*}$-stimulated taurine release from cultured astrocytes and LRM55 cells. J Ncurosci 10: 571-577.

Mayer ML (1985) A calcium-activated chloride current generates the after-depolarization of rat sensory ncurones in culture. J Physiol (Lond) 364:217-239.

McCarty NA, O'Neil RG (1990) Dihydropyridine-sensitive cell volume regulation in proximal tubule: the calcium window. Am J Physiol 259:F950-F960.

McCarty NA, O'Neil RG (1991a) Calcium-dependent control of volume regulation in renal proximal tubule cells. I. Swelling-activated $\mathrm{Ca}^{2+}$ entry and release. J Membr Biol 123:149-160.

McCarty NA, O'Neil RG (1991b) Calcium-dependent control of volume regulation in renal proximal tubule cells. II. Roles of dihydropyridine-sensitive and -insensitive $\mathrm{Ca}^{2+}$ entry pathways. J Membr Biol 123:161-170.

Meldolesi J, Volpe P, Pozzan T (1988) The intracellular distribution of calcium. Trends Neurosci 11:449-452.

Miledi R, Parker I (1984) Chloride current induced by injection of calcium into Xenopus oocytes. J Physiol (Lond) 357:173-183.

O'Connor ER, Kimelberg HK (1991) Effect of calcium on astrocyte volume regulation, ion and amino acid release. Soc Neurosci Abstr 17:56.

O'Connor ER, Kimelberg HK, Keese CR, Giaever I (1993) An electrical resistance method for measuring volume changes in monolayer cultures applied to astrocytic swelling. Am J Physiol, in press.

Olson JE, Sankar R, Holtzman D, James A, Fleischhacker D (1986) Energy-dependent volume regulation in primary cultured cerebral astrocytes. J Cell Physiol 128:209-215.

Olson JE, Fleischhacker D, Murray WB, Holtzman D (1990) Control of astrocyte volume by intracellular and extracellular $\mathrm{Ca}^{2+}$. Glia 3:405412.

Parsons DF, Cole RW, Kimelberg HK (1989) Shape, size, and dis- 
tribution of cell structures by 3D graphics reconstruction and stereology. I. Regulatory volume decrease of astroglial cells. Cell Biophys $14: 27-42$.

Pasantes-Morales HP, Schousboe A (1988) Volume regulation in astrocytes: a role for taurinc as an osmoeffector. J Neurosci Res 20 : 505-509.

Pasantes-Morales HP, Schousboe A (1989) Release of taurine from astrocytes during potassium-evoked swelling. Glia 2:45-50.

Pasantes-Morales H, Moran J, Schousboe A (1990) Volume-sensitive release of taurine from cultured astrocytes: properties and mechanism. Glia 3:427-432.

Pierce SK, Politis AD (1990) $\mathrm{Ca}^{2+}$-activated cell volume recovery mechanisms. Annu Rev Physiol 52:27-42.

Puro DG (1991) Stretch-activated channels in human retinal Muller cells. Glia 4:456-460.

Quandt FN, MacVicar BA (1986) Calcium activated potassium channels in cultured astrocytes. Neuroscience 19:29-41.

Rothstein A, Mack E (1990) Volume activated $\mathrm{K}$ and $\mathrm{Cl}$ pathways of dissociated epithelial cells (MDCK): role of $\mathrm{Ca}^{2+}$. Am J Physiol 258: C827-C834.

Rothstein A, Mack E (1992) Volume-activated calcium uptake: its role in cell volume regulation of Madin-Darby canine kidney cells. Am J Physiol 262:C339-C347.

Sarkadi B, Mack E, Rothstein A (1984) Ionic events during the volume response of human peripheral blood lymphocytes to hypotonic media. I. Distinction between volume activated $\mathrm{Cl}$ and $\mathrm{K}^{+}$conductance pathways. J Gen Physiol 83:497-512.

Shain WG, Martin DL (1984) Activation of $\beta$-adrenergic receptors stimulates taurine release from glial cells. Cell Mol Neurobiol 4:191196.

Shain W, Bausback D, Fiero A, Madelian V, Turner JN (1992) Reg- ulation of receptor-mediated shape change in astroglial cells. Glia 5:223-238.

Sykova E (1983) Extracellular $\mathrm{K}^{+}$accumulation in the central nervous system. Prog Biophys Mol Biol 42:135-189.

Sykova E (1991) Activity-related ionic and volume changes in neuronal microenvironment. In: Volume transmission in the brain: novel mechanisms for neural transmission (Fuxe K, Agnati LF, eds), pp 317-336. New York: Raven.

Thurston JH, Hauhart RE, Dirco JA (1980) Taurine: a role in osmotic regulation of mammalian brain and possible clinical significance. Lifo Sci 26:1561-1568.

Ubl J, Murer H, Kolb H-A (1988) Ion channels activated by osmotic and mechanical stress in membranes of opossum kidney cells. J Membr Biol 104:223-232.

Walz W (1989) Role of glial cells in the regulation of the brain ion microenvironment. Prog Neurobiol 33:309-333

Walz W, Wilson DC (1986) Calcium entry into cultured mouse astrocytes. Neurosci Lett 67:301-306.

Watson PA (1989) Accumulation of cAMP and calcium in S49 mouse lymphoma cells following hyposmotic swelling. J Biol Chem 264: 14735-14740.

Watson PA (1990) Direct stimulation of adenylate cyclase by mechanical forces in S49 mouse lymphoma cells during hyposmotic swelling. J Biol Chem 265:6569-6575.

Wong SME, Chase HS Jr (1986) Role of intracellular calcium in cellular volume regulation. Am J Physiol 250:C841-C852.

Wong SME, DeBell MC, Chase HS Jr (1990) Cell swelling increases intracellular free $\mathrm{Ca}$ in cultured toad bladder cells. Am J Physiol 258: F292-F296.

Yang X-C, Sachs F (1990) Characterization of stretch-activated ion channels in Xenopus oocytes. J Physiol (Lond) 431:103-122. 